ANETA NISIOBECKA

Archiwum IPN w Warszawie

\title{
ADAPTACJA REEMIGRANTÓW Z FRANCJI DO KOMUNISTYCZNEJ RZECZYWISTOŚCI W POLSCE LUDOWEJ W LATACH 1945-1954
}

Zarys treści: Przedmiotem analizy są nieomówione dotąd w literaturze przedmiotu procesy adaptacyjne Polaków przybyłych z ziemi francuskiej oraz ich konfrontacja $\mathrm{z}$ realiami stalinowskiej Polski. Istotny wpływ na badane problemy adaptacyjne miała kwestia adekwatności założeń komunistycznej polityki reemigracyjnej oraz związanych z nią składanych polskim robotnikom obietnic awansu zawodowego w stosunku do rzeczywistej sytuacji w kraju. Poczatek rozważań wyznacza rok zakończenia wojny, koniec - 1954 r., kiedy po śmierci Stalina i ucieczce Józefa Światły nastapiło złagodzenie kursu w działaniach aparatu bezpieczeństwa wobec środowiska reemigrantów.

W artykule omówiono powody, którymi Polacy kierowali się przy podejmowaniu decyzji o powrocie lub pozostaniu we Francji, a następnie przedstawiono konfrontację ich wyobrażeń o warunkach życia w Polsce Ludowej z powojenna rzeczywistością. W dalszej części zostały przybliżone postawy, zachowania i obyczaje reemigrantów osiedlonych na Górnym i Dolnym Ślasku oraz zagadnienia związane z inwigilacją środowiska reemigrantów przez Urząd Bezpieczeństwa, sprzeczne z propagandowymi założeniami polityki reemigracyjnej Polski Ludowej.

The content outline: The article focuses on, undiscussed so far in the literature on the subject, the adaptive processes of the Poles who came from France to Stalinist Poland, and their confrontation with the reality of Stalinist Poland. An important influence on the studied adaptation problems was exerted by the question of adequacy of principles of communist repatriation policy and its promises of professional promotion made to Polish workers in relation to the actual situation in the country. The chronological scope of the study is from the end of the war to the year 1954 when, after Stalin's death and the escape of Józef Światło, there was a "thaw" in actions of security services within the communities of repatriates.

The article presents motives of the Poles deciding to stay in France or leave it for Poland, and then a confrontation of their ideas about the conditions of life in People's Poland. The following part discusses the attitudes, behaviour, and 
customs of repatriates settled in Upper and Lower Silesia, and questions related to the surveillance of the repatriate community by the Security Office, at variance with propagandist assumptions of repatriate policy of the Polish People's Republic.

Słowa kluczowe: adaptacja, reemigracja z Francji, górnictwo, rolnicy, płace, warunki mieszkaniowe, inwigilacja

Keywords: adaptation, repatriation from France, mining, peasants, salaries, housing conditions, surveillance

Przyłączenie do Polski Ziem Odzyskanych i pozyskanie znajdujących się na ich terenie kopalń węgla kamiennego, a także wielohektarowych poniemieckich majątków spowodowało, że władze w Warszawie upomniały się w Paryżu o polskich obywateli zatrudnionych we francuskich kopalniach i gospodarstwach rolnych. Dla polskiego rządu było oczywiste, że znacząca rolę w rozwoju przemysłu kopalnianego w Polsce moga odegrać „siły z Francji”. Z uwagi na popularność ideologii komunistycznej w środowisku polskich robotników przychylność reemigrantów mogła być motywowana przede wszystkim ideologicznie, gdyż nie można im było zaoferować warunków socjalnych na poziomie francuskich. Polskie władze widziały $\mathrm{w}$ tej grupie zawodowej potężny rezerwuar ludzki, który mógł uzupełnić braki kadrowe w szeregach administracji państwowej, a także w Polskiej Partii Robotniczej. Ostatecznie z Francji do Polski wróciło ok. 140 tys. obywateli ${ }^{1}$.

Pomimo niechęci rządu francuskiego wobec utraty wykwalifikowanych kadr (górników, rolników i robotników przemysłowych) w kopalniach i gospodarstwach reemigracja była możliwa dzięki zawartym czterem porozumieniom polsko-francuskim: z 20 II, 10 IX i 28 XI 1946 r. oraz 24 II 1948 r.

Przedmiotem analizy są nieomówione dotąd w literaturze przedmiotu procesy adaptacyjne Polaków przybyłych z ziemi francuskiej oraz ich konfrontacja z realiami Polski Ludowej, a także adekwatność założeń komunistycznej polityki repatriacyjnej i reemigracyjnej oraz składanych polskim robotnikom obietnic awansu zawodowego $\mathrm{w}$ stosunku do rzeczywistej sytuacji w stalinowskiej Polsce.

${ }^{1}$ Łączną liczbę repatriantów powracających do Polski szacuje się na 3798715 osób; Rocznik statystyczny 1949. Gtówny Urzad Statystyczny RP, Warszawa 1950, s. 26; H. Jędruszczak, Zatrudnienie a przemiany spoteczne $w$ Polsce $w$ latach 1944-1960, Wrocław 1972, s. 111. Według informacji zawartych w: Wysiedlenia, wypędzenia i ucieczki 1939-1959. Atlas ziem Polski, red. W. Sienkiewicz, G. Hryciuk, Warszawa 2008, s. 83-87, do Polski przybyło ok. 3,6 mln osób. 
Początek rozważań, co oczywiste, wyznacza rok zakończenia wojny. Wyjaśnienia natomiast wymaga cezura końcowa artykułu. Od momentu podpisania pierwszej konwencji o reemigracji i powrocie pierwszych górników i rolników do Polski zaczął się proces przystosowywania się do nowej rzeczywistości. Trudno jednoznacznie stwierdzić, kiedy ten proces się kończy. Ze sprawozdań m.in. Ministerstwa Ziem Odzyskanych i resortów spraw bezpieczeństwa dotyczących życia powracających do kraju rodaków wynika, że budzili oni duże ich zainteresowanie, szczególnie w latach 40. i 50., a nawet 60. ubiegłego wieku. Największe natężenie zainteresowania organów bezpieczeństwa reemigrantami przypadło na okres stalinowski. Odwilż w działaniach bezpieki wobec środowiska reemigrantów była odczuwalna od 1954 r., po śmierci Stalina i ucieczce Józefa Światły².

\section{„Wracać czy zostać?” - dylematy Polaków we Francji}

Kształt rzeczywistości pojałtańskiej sprawił, że wielu Polaków przebywajacych poza krajem stanęło przed dylematem powrotu do kraju lub pozostania na obczyźnie. Zarzucani informacjami przez zwalczające się wzajemnie przedstawicielstwa - rządu londyńskiego i warszawskiego próbowali dokonać oceny w chaosie sprzecznych informacji o sytuacji politycznej nad Wisła. Wśród emigracji politycznej znaleźli się jednak politycy, generałowie i ludzie pióra, którzy zaakceptowali nowy układ w Europie ${ }^{3}$. Decyzja Stanisława Mikołajczyka o powrocie do Polski i przyjęciu stanowiska wicepremiera w Tymczasowym Rządzie Jedności Narodowej miała wpływ na ocenę realiów życia w Polsce oraz decyzje Polaków przebywajacych poza krajem ${ }^{4}$.

W tej powojennej rzeczywistości „dyskusja powrotowa” nie ominęła również organizacji polonijnych oraz środowiska emigracji zarobkowej we Francji. Działały tu zarówno organizacje polonijne, popierające rząd emigracyjny w Londynie, jak i te, które wspierały nowe władze krajowe.

2 J. Wróbel, Działania Ministerstwa Bezpieczeństwa Publicznego przeciwko repatriantom z Zachodu w latach 1945-1953, w: Aparat bezpieczeństwa wobec emigracji politycznej i Polonii, red. R. Terlecki, Warszawa 2005, s. 239.

${ }^{3}$ R. Habielski, Życie społeczne i kulturalne emigracji, w: Druga Wielka Emigracja 1945-1990, t. 3, Warszawa 1999, s. 14-18; J.A. Radomski, Demobilizacja Polskich Sit Zbrojnych na Zachodzie w latach 1945-1951, Kraków 2009, s. 38, 58.

${ }^{4}$ Więcej o repatriacyjnej debacie wśród emigracji „londyńskiej” zob. J. Wróbel, $N a$ rozdrożu historii. Repatriacja obywateli polskich z Zachodu w latach 1945-1949, Łódź 2009, s. 188-253. 
Polemiki były ostre, a jedna $\mathrm{z}$ najważniejszych osi sporu stanowił stosunek do repatriacji i reemigracji.

Komunistyczna proweniencję miały organizacje utworzone jeszcze przed wojną oraz w jej trakcie, m.in.: Polskie Grupy Językowe (istniały w strukturach Francuskiej Partii Komunistycznej, FPK), Organizacja Pomocy Ojczyźnie (OPO), Związek Młodzieży Polskiej „Grunwald”, Organizacja Młodzieży Towarzystwa Uniwersytetu Robotniczego, Polski Komitet Wyzwolenia Narodowego we Francji ${ }^{5}$. Rada Narodowa Polaków we Francji, przekształcona podczas II Zjazdu PKWN we Francji (Paryż, 28-30 VII 1945 r.), była największą i najważniejsza polonijna struktura popierająca komunistyczny rząd w Polsce ${ }^{6}$. Po drugiej stronie znalazły się stowarzyszenia przeciwne nowo formującemu się w Polsce systemowi oraz reemigracji: Centralny Zwiąek Polaków, Polskie Zjednoczenie Katolickie oraz Polska Organizacja Walki o Niepodległość „Monika”.

W celu pozyskania przychylności Polaków do rządu w Warszawie i reemigracji organizacje prowarszawskie regularnie organizowały spotkania z Polakami. Najwięcej posiedzeń, głównie w regionie górniczym północnej Francji i Lotaryngii, odbyło się w okresie 1945-1946, tj. w trakcie negocjacji polsko-francuskich na temat podpisania pierwszej umowy o reemigracji górników dołowych ${ }^{7}$. Duża frekwencja nie była zaskoczeniem,

${ }^{5} \mathrm{O}$ działalności PKWN we Francji więcej zob. m.in.: K. Maj, Polskie Komitety Wyzwolenia Narodowego we Francji (luty 1944-1945), „Z Pola Walki” 1974, nr 2, s. 91-121; taż, Polscy komuniści we Francji 1919-1946, Warszawa 1971, s. 135-191.

${ }^{6} \mathrm{O}$ organizacjach polonijnych po zakończeniu wojny więcej zob.: D. Jarosz, M. Pasztor, Robineau, Bassaler i inni. Z dziejów stosunków polsko-francuskich w latach 1948-1953, Toruń 2001, s. 34-38; L. Turajczyk, Społeczno-polityczne organizacje polskie we Francji 1944-1948, Warszawa 1978, s. 58-156; tenże, Polonijne organizacje społeczno-polityczne we Francji i ich postawa wobec powrotu emigracji zarobkowej do kraju (1945-1948), „Materiały i Studia z Najnowszej Historii Polski” 3, 1967, s. 47-53; J. Ponty, Polskie organizacje we Francji po drugiej wojnie światowej, w: Organizacje polonijne $w$ Europie Zachodniej. Wspótczesność i tradycje. Materiały z konferencji naukowej $w$ dniach 2 i 3 kwietnia 1987 r. w Poznaniu, red. B. Szydłowska-Cegłowa, J. Kozłowski, Poznań 1991; Z. Girzyński, Walka o wpływy wśród Polonii we Francji $w$ latach 1945-1952, w: Ze studiów nad polskim dziedzictwem w świecie. Księga dedykowana profesorowi Edmondowi Gogolewskiemu, red. L. Nowak, M. Szczerbiński, Gorzów Wielkopolski 2002; tenże, Walka o „rzad dusz” $w$ młodym pokoleniu polskich emigrantów we Francji na przykładzie Zwiazku Młodzieży Polskiej „Grunwald”, w: Młode pokolenie polskich emigrantów - jego losy i problemy $w$ XX wieku. Zbiór studiów, red. R. Studziński, Włocławek 2004; Archives Départementales du Pas-deCalais à Arras-Dainville (dalej: $\mathrm{AD} \mathrm{PdC}$ ), sygn. $1 \mathrm{Z} \mathrm{463,} \mathrm{nr} \mathrm{4565-FT,} \mathrm{Objet:} \mathrm{a.s.} \mathrm{les}$ étrangers en France - les organisations polonaises - le Conseil National des Polonais en France, source: directe, valeur: sûre, 21 XII 1945 r., b.p.

7 AD PdC, sygn. M 3234, Renseignements Géneraux, Béthune, Chapitre II, Les questions étrangères, 2 VII 1945 r., b.p.; AD PdC, sygn. M 3235, Le Commissaire de 
głównie dlatego, że Polacy wykazywali spore zainteresowanie informacjami na temat sytuacji w ojczyźnie, a także na temat kwestii prawnych związanych z reemigracja. Bezustannie powtarzano górnikom, że polskie kopalnie potrzebują wykwalifikowanych specjalistów, nazywając reemigrację „narodowa koniecznością”.

Byłoby jednak zbytnim uproszczeniem twierdzić, że środowisko emigracji zarobkowej bez zastrzeżeń odnosiło się do pomysłu powrotu do kraju. Rodziny rolnicze, a przede wszystkim górnicy, nie byli tak mocno przeświadczeni o konieczności reemigracji jak emigranci wojenni lub renciści. W przypadku podjęcia decyzji o powrocie musieli się bowiem liczyć z utratą przywilejów emerytalnych, wyraźna była też obawa przed warunkami życia w Polsce. Negatywnie odnosiły się do powrotu żony górników oraz dzieci, które urodziły się we Francji lub tam dorastały. Dużym problemem w pozyskaniu młodzieży do idei powrotu była słaba znajomość tradycji i historii kraju ojców. Ci młodzi ludzie, którzy „uczuciowo przylgnęli do nowego kraju”, byli związani z francuskim środowiskiem, biegle posługiwali się językiem francuskim, polskie środowisko oraz polską kulturę uważali za coś obcego ${ }^{9}$. Jak zauważa Leon Turajczyk, komunistyczny rząd polski oficjalnie popularyzując ideę zjednoczenia emigracji polskiej na ziemiach zachodnich, po cichu zdawał sobie sprawę, że część górniczej emigracji pozostanie we Francji ${ }^{10}$. Takie samo stanowisko zajmowali także eksperci ds. osadnictwa na Ziemiach Odzyskanych, którzy już wówczas zwracali uwagę, że sukcesem polskiej polityki będzie powrót do kraju „dużej części emigracji”11.

W „Narodowcu” - polskim czasopiśmie emigracyjnym wydawanym we Francji od 1924 r. - pisano wprost, że istotną rolę w podjęciu decyzji o powrocie do kraju odgrywała tęsknota za Polska. Stwierdzano, że dla polskiego reemigranta, który w obcym kraju ,jadł i je tylko gorzki chleb,

Police aux Renseignements Généraux à Monsieur le Commissaire devisionnaire, Chef du Service Régional des Renseignements Généraux, objet: a.s. rapport monsuel sur l'activité des ressortissants étrangers, Lens, 20 VII 1945 r., b.p.

8 Archives du Ministère des Affaires Étrangères (dalej: AMAE), Europe 1944-1960, Pologne 1944-1949, sygn. 85, Le Ministre des Affaires Étrangères à l'Ambasade de France à Londre, Paris, 25 XI 1945 r., k. 12.

9 AAN, Ministerstwo Ziem Odzyskanych (dalej: MZO), sygn. 2202, Problem sił pracowniczych w przemyśle Ziem Odzyskanych, b.d., k. 59.

${ }^{10}$ L. Turajczyk, Polonijne organizacje spoteczno-polityczne..., s. 54-55, 59; AD PdC, sygn. M 3235, nr 1524, Note de renseignement, objet: directe, velur: sûre, objet; situation des groupements étrangers, Béthune, 9 VIII 1945 r., b.p.

${ }^{11}$ AAN, MZO, sygn. 2202, Zagadnienie sił roboczych w przemyśle węglowym nowej Polski, b.d., k. 61. 
powrót jest rzeczą naturalną". Ważną rolę w decyzji o powrocie do ojczyzny odgrywały czynniki materialne: powrót odbywał się na koszt państwa ${ }^{12}$.

Jednak o pozostaniu we Francji zadecydowały przede wszystkim kwestie materialne. Otóż Francja, której ze względu na brak rodzimej siły roboczej zależało na zatrzymaniu polskich górników, podjęła działania zmierzajace do poprawy ich sytuacji materialnej i socjalnej. W czerwcu 1945 r. rząd francuski o 12,5\% podwyższył pensję górnikom pracującym na powierzchni i o $25 \%$ - górnikom dołowym. Działania władz francuskich nie były adresowane tylko do sektora górniczego. Regulacje związane $\mathrm{z}$ odnowieniem kart tożsamości dotyczyły wszystkich cudzoziemskich robotników. Rozporządzenie Tymczasowego Rządu Republiki Francuskiej z 19 X 1945 r. wprowadzało zwolnienie z opłat przy odnawianiu dowodów tożsamości oraz gwarantowało cudzoziemskim robotnikom pierwszeństwo $\mathrm{w}$ staraniu się o naturalizację. Zainteresowanych obcokrajowców zwolniono także z opłat przy składaniu formularzy o naturalizacje $e^{13}$.

W latach 1946-1949 przez domy reemigrantów przetoczyły się burzliwe dyskusje. Dylemat „zostać czy wracać?” towarzyszył codziennie polskim rodzinom. Kalkulowano, wyliczano argumenty pour ou contre. Górnicy polscy obawiali się, że „braknie sił na rozpoczęcie nowego życia, na przyzwyczajenie się do nowych warunków, które mogą okazać się nie najlepsze" ${ }^{14}$. Lecz decyzjami rodziców kierowała również troska o przyszłość potomków, którzy nie mogli liczyć we Francji na awans społeczny, a szansę dlań upatrywali w reemigracji. Wielu emigrantów zatrzymywał we Francji strach przed „polską biedą”, która wygnała ich z kraju, a także wizja utraty ciężko wypracowanego dobytku ${ }^{15}$.

\section{Konfrontacja z komunistyczną rzeczywistością w Polsce}

Po trudnych dyskusjach, nadziejach na lepszą przyszłość w Polsce Ludowej, rozczarowania i przerażenia reemigranci doświadczali już na pierwszej stacji przesiadkowej w Międzylesiu. W jednym z raportów

${ }^{12}$ B. Surówka, Co widziat $i$ styszał $w$ pótnocnej Francji przedstawiciel krajowego dziennika, „Narodowiec” 5 X 1946, s. 1, 3.

13 Bezpłatne karty tożsamości dla górników-cudzoziemców, ich żon oraz dzieci, „Narodowiec” 7-8 X 1945, s. 1; J. Ponty, L’immigration dans les textes. France, 1789-2002, Berlin-Paris 2004, s. 288-290.

${ }_{14}$ M. Bugzel, Wspomnienia starego emigranta, w: Pamiętniki emigrantów 1878-1958, wybór i oprac. K. Koźniewski, Warszawa 1960, s. 71.

${ }_{15}$ W. Markiewicz, Przeobrażenia świadomości narodowej reemigrantów polskich z Francji, Poznań 1960, s. 148, 150-151. 
Ambasady RP w Paryżu do MSZ w Warszawie napisano: „Żadne oficjalne powitania nie mogły zatrzeć pierwszego wrażenia". Pierwsze wrażenie to były rozmowy z Polakami, którzy oblegali każdy kolejny transport wjeżdżajaccy na terytorium Polski i nakłaniali do powrotu do Francji z powodu panujacej w Polsce biedy ${ }^{16}$.

Koszty utrzymania w tużpowojennej Francji były wprawdzie wysokie, ale nie ulega wątpliwości, że sytuacja materialna większej części rodzin w Polsce była dramatyczna ${ }^{17}$. Z cytowanych rozmów przeprowadzonych przez reportera francuskiego tygodnika „Témoignage Chrétien" (wydawanego w Lyonie) z przybyłymi z Francji górnikami, zatrudnionymi w kopalni „Wujek” w Katowicach, wynikało, że większość z nich uważała warunki w Polsce za prymitywne i trudne. Wyrażali żal z powodu opuszczenia Francji i chcieli tam wrócićc ${ }^{18}$. Słusznie zresztą władze w Polsce obawiały się, że opinia pierwszych reemigrantów będzie miała wpływ na losy pozostałej części Polaków we Francji, którzy zdecyduja, aby nie wyjeżdżać.

W polityce władz polskich widoczne były sprzeczności: z jednej strony uważano, że należy dążyć do poprawy warunków bytowych górników-reemigrantów z obawy przed słabym wynikiem reemigracyjnym, z drugiej zaś w działaniach władz polskich nie widać było wyraźnego dążenia do ich poprawy. Analiza dokumentów archiwalnych nie pozostawia wątpliwości, że relacje pierwszych reemigrantów przełożyły się na przebieg i powodzenie dalszej reemigracji.

Jednym z głównych celów polskiej polityki reemigracyjnej było pozyskanie fachowych kadr do kopalń dolnośląskich, dlatego większość polskich górników otrzymała pracę w kopalniach w okolicach Wałbrzycha, nazywanego „stolicą węgla kamiennego”. Obok Wrocławia był

${ }^{16}$ Archiwum Ministerstwa Spraw Zagranicznych w Warszawie (dalej: AMSZ), z. 22, w. 3, t. 61, Pismo attaché Ambasady RP w Paryżu W. Wierbłowskiej i kierownika Repatriacji Ambasady RP w Paryżu T. Oppmanna w sprawie reemigracji górników z Francji, Paryż, 11 XI 1946 r., k. 2.

${ }_{17}$ Dziennikarz francuski opowiada jak żyja górnicy $w$ Wałbrzychu, „Gazeta Polska” 22 III 1949, s. 3; A. Krzemień, Górnictwo węgla kamiennego w Zagtębiu Dabrowskim w latach 1945-1949, praca dokt. pod kier. doc. dr. hab. A. Topola, Wydział Nauk Społecznych Uniwersytetu Ślaskiego, Katowice 2007, s. 139-141, http://www.sbc.org.pl/ Content/7024/doktorat2753.pdf, 24 II 2015 r.; J. Chumiński, Ruch zawodowy w Polsce $w$ warunkach ksztattujqcego się systemu totalitarnego: 1944-1956. Wrocław 1999, s. 133; A. Girard, Les conditions d'existance des familles. Dépenses et ration alimentaire en janvier - février 1948, „Population” 3, 1948, nr 2, s. 351, 354, 357; J.P. Rioux, La France de la IV République, t. 1: L’ardeur et la nécessité 1944-1952, Paris 1980, s. 103 (Nouvelle histoire de la France contemporaine, 15).

${ }^{18}$ W sprawie górników polskich we Francji, „Narodowiec” 16-17 XII 1945, s. 3. 
największym miastem w regionie dolnoślaskim. Działały tu kopalnie: „Victoria”, „Thorez”, „Chrobry” i „Mieszko” (wcześniej „Melchior”), gdzie wydobywano wysokowartościowy węgiel koksujący.

To właśnie do Wałbrzycha trafiło najwięcej reemigrantów z Francji, a na ulicach miasta dominował francuski i z tego powodu mówiono, że „Wałbrzych to Francja”, nazywając go „francuskim miastem”, a górników-reemigrantów - „Francuzami”"19. W 1948 r. w powiecie wałbrzyskim osiedliło się ok. 40 tys. reemigrantów z Francji ${ }^{20}$. Obok „Francuzów” w Wałbrzychu osiedlali się także repatrianci „zza Buga” oraz reemigranci, którzy przybyli na Ziemie Zachodnie bezpośrednio z Westfalii i Nadrenii. Przyjeżdżali tu także Polacy z centralnych regionów kraju oraz Żydzi. Mozaikę narodowościową wzbogacili Grecy, ewakuowani do Polski w latach 1946-195121.

Pomimo propagandowych zapewnień o lepszych warunkach pracy niż w kopalniach we Francji poważne braki w infrastrukturze i sprzęcie zmuszały górników do jeszcze większego wysiłku. Górnicy „francuscy” z kopalni „Mieszko” skarżyli się przewodniczacemu Rady Zakładowej (zresztą reemigrantowi z Francji), że w kopalni brakowało nowoczesnych narzędzi: świdrów powietrznych, kilofów, lamp ${ }^{22}$. Brak części maszynowych odnotowywany był również w kopalniach na Górnym Ślasku, m.in. w kopalni „Bolesław Śmiały” w Łaziskach Górnych, co utrudniało w znaczący sposób „utrzymanie ruchu w kopalni” ${ }^{23}$. Nie da się zaprzeczyć, że w polskich kopalniach z powodu braku podstawowych narzędzi, a także funduszy na modernizację oraz trudnych warunków geologicznych warunki pracy były katorżnicze ${ }^{24}$.

${ }_{19}$ Oblicze demokracji ludowej. „Wałbrzych to jeszcze Francja”- mówia ślascy górnicy, „Gazeta Polska” 14 X 1948, s. 2.

${ }^{20}$ Archiwum Instytutu Pamięci Narodowej Oddział we Wrocławiu (dalej: AIPN Wr), sygn. 037/76, Historia obiektu po zagadnieniu środowiska repatriantów z Francji, Wałbrzych, 20 XII 1948 r., k. 5.

${ }_{21}$ W. Markiewicz, dz. cyt., s. 164-165; A. Małkiewicz, Październik 1956 r. w Watbrzychu, w: Październik na Ziemiach Zachodnich i Pótnocnych. Materiaty seminarium naukowego, Mierki k. Olsztyna, wrzesień 1996, red. W. Wrzesiński, Wrocław 1997, s. 80.

${ }^{22} \mathrm{Na}$ ziemiach polskich. Kopalnie, w których będa pracować nasi górnicy. Wywiad z Konsulem Generalnym ob. Tomaszem Piętkq, „Gazeta Polska” 13 IV 1946, s. 3; (Wej), Korespondent „Dziennika Zachodniego”, „Ciesze się, że jestem w Ojczyźnie”. Z wizyta u górników Zagłębia Wałbrzyskiego, „Gazeta Polska” 16 XI 1946, s. 3; B. Turski, Wizyta u górników w Wałbrzychu, „Gazeta Polska” 31 XII 1946, s. 4.

${ }^{23}$ Archiwum Instytutu Pamięci Narodowej w Warszawie (dalej: AIPN), sygn. 01265/81, Raport dekadowy WUBP w Katowicach od 10 do 30 VI 1946 r. [sic!], Warszawa, 24 VI 1946 r., k. 39 (numeracja pdf).

${ }^{24}$ A. Korzekwa, 10 tysięcy mieszkań przygotowuje się $w$ Polsce dla reemigrantów-górników, „Gazeta Polska” 2 VII 1947, s. 2; Rozmawiamy z górnikami-repatriantami, 
Rozczarowaniem okazała się również obiecywana przez władze w Polsce szybka droga kariery zawodowej. Symbolicznie przedstawił to „Narodowiec”, cytując list jednego z reemigrantów. Twierdził, że ścieżka kariery w Polsce Ludowej może być bardzo krótka: dygnitarzem w jednej chwili może stać się np. górnik lub robotnik, jeśli tylko zdobędzie „dyplom pepeerowski”. Autor listu przyznawał, że reemigranci powrót do Polski traktowali jako własną przegrana, przeklinając wszystkich, którzy przyczynili się „do zrujnowania szczęścia rodzinnego i materialnego tych ofiar" 25 . Nie ulega wątpliwości, że awans z klucza partyjnego był zasadnicza kwalifikacją do objęcia kierowniczych stanowisk przez reemigrantów z Francji. Przykładem jest kariera reemigranta Jana Warownego, który we Francji był prezesem Rady Narodowej okręgu Pas-de-Calais. W Polsce otrzymał stanowisko zastępcy dyrektora Dolnośląskiego Zarządu Przemysłu Węglowego ${ }^{26}$.

Co gorsza, wpływ na politykę kadrową w zakładach przemysłowych miały urzędy bezpieczeństwa, decydujace o awansach nie według potrzeb gospodarczych i ekonomicznych, lecz według „klucza partyjnego”. Największy stopień „upartyjnienia” obserwowano na stanowiskach dyrektorskich i kierowniczych. W 1950 r. na 1777 osób zatrudnionych na stanowiskach dyrektorskich 1301 posiadało legitymację PZPR (73,2\%), tylko 422 osoby były bezpartyjne. Połowa osób zatrudnionych na stanowiskach majstrów, sztygarów i inżynierów „nosiła w kieszeni” legitymację partyjna. Bezpieka decydowała również o losach pracowników: zwolnieniach, awansach, przenosinach na inne stanowiska lub kierowaniu do innych zakładów pracy ${ }^{27}$.

Procent osób, które spośród tych kilkudziesięciu tysięcy „Francuzów” otrzymały awans i związane z tym przywileje, nie był duży. Pozostałych

„Gazeta Polska” 20-21 VI 1948, s. 3; P. Retecki, Górnictwo w Wałbrzychu w latach 1945-1948, Wrocław 2010, s. 109-110; AAN, Rada Narodowa Polaków we Francji (dalej: RNPwF), sygn. mf 1927/11, t. 95 (354/IV-95), Serge Karsky, En Pologne avec les rapatriés. Le mineur de fond gagne en Silésie beaucoup moins qu’en France, „La Voix du Nord", 17 VI 1947 r., k. 63.

25 Barabasz, Przyczyny zła, „Narodowiec” 3 VII 1948, s. 2.

${ }^{26}$ Warowny, Jak spędziłem „Gwiazdkę” wśród górników z Francji w Wałbrzychu, „Gazeta Polska” 16 I 1947, s. 2; Watbrzych miasto reemigrantów (Korespondencja własna $z$ Watbrzycha [Ślask]), „Gazeta Polska” 3 VIII 1950, s. 3; Repatrianci z Francji na odpowiedzialnych stanowiskach w Kraju (Korespondencja wtasna), „Gazeta Polska” 17 VIII 1950, s. 3.

27 J. Chumiński, Wptyw aparatu bezpieczeństwa na sytuację kadrowa $w$ przemyśle polskim w latach 1945-1956 w: „Budujemy socjalizm...”. Materiaty pokonferencyjne, red. R. Klementowski, S. Ligarski, Wrocław 2010, s. 22, 30; tenże, „Nowa inteligencja” $w$ polskich zakładach przemystowych 1945-1956, „Kwartalnik Historyczny” 2006, nr 4 , s. 23. 
ogarniało uczucie beznadziei i żalu z powodu decyzji o przyjeździe do Polski. Rozczarowani, a wręcz przerażeni warunkami życia w Polsce, reemigranci błagali o pomoc na łamach „Narodowca”. Zdzisław Cedler, syn górnika-reemigranta, twierdzi, że uczucie rozczarowania wśród górników w środowisku remigracyjnym było powszechne ${ }^{28}$.

Ton relacji na temat emigrantów w „Narodowcu” znajduje potwierdzenie w dokumentach francuskiego MSZ oraz raportach struktur bezpieczeństwa publicznego z lat 1947-1950. W 1947 r. Ambasada Francji w Polsce informowała swoją centralę, że do konsulatu francuskiego w Katowicach w okresie od stycznia do marca 1947 r. wpłynęło 350 podań od polskich reemigrantów z prośbą o zgodę na powrót do Francji. Słów krytyki na temat polskiej rzeczywistości nie szczędzili członkowie FPK i OPO, którzy w Polsce należeli do PPR, a potem PZPR. Uzyskanie zgody na wyjazd do Francji w okresie narastającego napięcia między Warszawą i Paryżem nie było jednak łatwe, a to pogłębiało jeszcze uczucie rozpaczy ${ }^{29}$.

Górnicy we Francji należeli do najlepiej opłacanej grupy zawodowej, w Polsce było inaczej. Potwierdza to jeden z pracowników francuskich kopalni o nazwisku Kramarz (imię nieznane), który stwierdził, że po powrocie do ojczyzny Polakom oferowano „dużo gorsze warunki, tak materialne, jak i mieszkaniowe" ${ }^{30}$. Pod tym względem rząd polski

${ }^{28}$ Dom Spotkań z Historia, Archiwum Historii Mówionej (dalej: DSH, AHM), sygn. 1140, Relacja Zdzisława Cedlera.

${ }^{29}$ AMAE, Europe 1944-1960, Pologne 1944-1949, sygn. 85, M. Jean de Beausse chargé d'affaires de France a.i. en Pologne à Son Excellence Monsieur Georges Bidault Minisitre des Affaires Étrangères, Paris, confidentiel, a.s. rapatriement des mineurs polonais, 31 III 1947 r., k. 133-135; AMAE, Europe 1944-1960, Pologne 1944-1949, sygn. 87, Direction des Conventions Administratives et Sociales, Note pour la Service d'Information et de Presse (à l'attention de M. Basdevant), a.s. film de propagande pour le rapatriement des mineurs polonais, 18 V 1947 r., k. 118; tamże, Guy Monge, Vice Consul de France à Wroclaw à Son Excellence Monsieur Georges Bideault, Ministre des Affaires Étrangères (Sous-direction de l'Europe Orientale), Paris, 22 V 1947 r., k. 119-120; AD PdC, sygn. 1 Z 1087, nr 4424 - SE, Objet: rapatriement des mineurs polonais, source: directe, valeur: sûre, Lens, 17 XII 1946 r., b.p; AD PdC, sygn. M 3237, nr 1192 SE, Objet: a.s. situation actuelle de la Pologne, source: sondages, valeur: sûre, Lens, 5 VI 1947 r., b.p.; AIPN, sygn. 01355/69, Spis reemigrantów przechodzących przez rozpr[acowanie] Sek[cji] III Wydz[iału] I członków Partii przejawiających wroga działalność, Katowice, 16 VI 1950 r., k. 11 (numeracja pdf); tamże, Zagadnienia reemigrantów, 1. Sprawa obiektowa „4-F”, Katowice, 3 VII 1950 r., k. 12 (numeracja pdf); AIPN, sygn. 01265/86, Sprawozdanie miesięczne od 1 do 30 VI 1951 r. sporządzone przez WUBP w Katowicach dla ministra bezpieczeństwa publicznego w Warszawie gen. dyw. S. Radkiewicza, Katowice, 14 VII 1951 r., k. 82-83 (numeracja pdf).

30 AAN, MZO, sygn. 69 (mf B-5171), Protokół zebrania odbytego w Delegaturze na Francję Generalnego Pełnomocnika Rządu RP do Spraw Repatriacji z udziałem przedstawicieli Centralnego Zarządu Przemysłu Węglowego, 14 VIII 1947 r., k. 77. 
wykazał się krótkowzrocznością. Nie pomogły apele starostw powiatowych, zwracające uwagę władz na konieczność poprawy warunków życia górników zaraz po rozpoczęciu akcji reemigracyjnej ${ }^{31}$.

Jednym z rozczarowanych Polską działaczy komunistycznych był Władysław Biernat, który stwierdził wprost, że wracając do Polski, dużo stracił. Jego list adresowany był w 1949 r. do przyjaciół we Francji. Biernat zwracał uwagę na nierówne traktowanie górników, twierdząc, że tylko jemu - w przeciwieństwie do jego kolegów - zaoferowano w Polsce duże poniemieckie mieszkanie. Górnik przestrzegał przed mówieniem prawdy na temat warunków pracy i życia. Tych, którzy odważyli się to zrobić głośno, nazywa się „faszystami”. Autor listu przyrównał sytuację do czasów przedwojennych, kiedy to „komunistami” nazywano w Polsce krytyków systemu sanacyjnego. Jego zdaniem na krytykę zasługiwał też system pracy w kopalni, który narzucał obowiązek pracy także w niedziele. Zdaniem Biernata jedynie „morderczy” wysiłek górnika był $\mathrm{w}$ stanie zapewnić mu w Polsce w miare przyzwoite zarobki, dlatego większość jego kolegów decydowała się na pracę po dziesięć godzin dziennie (miesięczna pensja przy pracy w ośmiogodzinnym dziennym wymiarze godzin wynosiła ok. 10 tys. zł).

Biernat krytykował też restrykcje $\mathrm{z}$ powodu nieobecności w pracy: absencja chorobowa skutkowała obniżeniem pensji nawet o 5 tys. zł, czyli prawie o połowę. Autor listu, zwolniony z powodu pylicy płuc, pisał także, że nie mógł liczyć w Polsce na pomoc socjalna. Zwrócił uwagę na bardzo wysokie ceny produktów podstawowych (fortement augmenté) i kończył list słowami: „Jest mi wstyd, że piszę do was o tym, ponieważ znacie moje poglądy komunistyczne" 32 .

Informacje o niskich zarobkach w polskich kopalniach potwierdza raport konsulatu francuskiego w Katowicach, w którym stwierdzono także, że sytuacja materialna górników i robotników nie poprawiała się od momentu przybycia do Polski. Podobne informacje o pensjach górniczych można odnaleźć w pracach historyków górnictwa. Pod koniec 1946 r. przeciętnie wynagrodzenie górnicze wynosiło 5841 zł, a wysokość przydziału kartkowego - 5722 zł (razem 11563 zł), pod koniec 1947 r. pensja górnicza (łącznie z wynagrodzeniem kartkowym)

${ }^{31}$ AAN, MZO, sygn. 273 (mf B-5377), Protokół czwartego zebrania periodycznego naczelników władz i urzędów niezespolonych odbytego 15 X 1948 r. o godz. 10 w starostwie powiatowym kłodzkim pod przewodnictwem starosty kłodzkiego Dawidiuka Mikołaja, [15 X 1948 r.], k. 286.

${ }^{32} \mathrm{~W}$ dokumentach nie ma informacji o dalszych jego losach po odejściu z kopalni; AD PdC, sygn. M 3230, nr 401-SE, Objet: a.s: situation actuelle en Pologne, source: informateur, valeur: très bonne, Lens, 7 III 1949 r., b.p. 
wynosiła średnio 17816 zł. Górnicy pracujący pod ziemią w grudniu 1946 r. mogli liczyć na zarobki w wysokości 6089 zł miesięcznie, a dwa lata później ich pensja wynosiła 16485 zł. Lepiej opłacani byli rębacze, których pensja w grudniu 1946 r. wynosiła 7816 zł, a w grudniu 1948 r. wzrosła do 20460 zł. Najmniej zarabiali górnicy pracujący na powierzchni. Ich pensje wynosiły od $3406 \mathrm{zł} \mathrm{w}$ grudniu 1946 r. do $10178 \mathrm{zł} \mathrm{w}$ grudniu $1948 \mathrm{r}^{33}$

Skargi „francuskich” górników na zarobki były powszechne. Autorem innego listu jest Stanisław Bogdański, który po powrocie z Francji osiedlił się w Jedlinie-Zdroju. Jako jedyny żywiciel rodziny dostawał pensję w wysokości 3 tys. zł miesięcznie, co nie pozwalało na utrzymanie pięcioosobowej rodziny, skazując ją na życie na granicy ubóstwa. Górnik nie otrzymywał też przydziałów węgla z kopalni, tak że węgiel trzeba było nosić „we woreczkach [codziennie] idąc z pracy”. Przestrzegał, że francuscy reemigranci „masowo wyjeżdżaja” do konsulatu francuskiego we Wrocławiu, starajac się o powrót do Francji ${ }^{34}$. Poruszający jest zwłaszcza dopisek do listu, w którym porównał on pozycję w kopalni górników z Francji i Niemców: „Niemcy dwa razy więcej [od nas] zarabiaja, i przeważnie Niemcy sa [sztygarami] i my u Niemców musimy robić, tak że my jesteśmy tą niższa rasa niż oni” ${ }^{35}$. Ta konstatacja oddaje ogromne rozgoryczenie „Francuzów” sytuacją w Polsce i ich żal z powodu niespełnionych obietnic awansu zawodowego.

Guy Monge, konsul francuski we Wrocławiu, stwierdził w raporcie do ministra spraw zagranicznych Francji Roberta Schumana,

${ }_{33}$ AMAE, Europe 1944-1960, Pologne 1944-1949, sygn. 87, [copie] M.C. Martin, Consul Général à Katowice à Son Excellence Monsieur le Ministre des Affaires Étrangères, Direction de l'Europe, a.s. mineurs polonais rapatriés en Pologne, Katowice, confidentiel, 9 VI 1947 r., k. 121; A. Krzemień, dz. cyt., s. 140-141. W czerwcu 1946 r. przeciętna płaca robotnika zatrudnionego w przemyśle wynosiła 5934 zł miesięcznie (łącznie ze świadczeniami otrzymywanymi w naturze i przydziałami kartkowymi), w listopadzie 1947 r. przeciętna pensja robotnika wynosiła 12347 zł; J. Chumiński, Ruch zawodowy $w$ Polsce..., s. 129-131.

${ }^{34}$ AAN, MZO, sygn. 836 (mf B-5957), Prośba Stanisława Bogdańskiego, repatrianta z Jedliny-Zdroju, Wałbrzych, b.d., k. 42-43. Dostarczanie obowiązkowych przydziałów węgla we własnym zakresie potwierdza także raport ambasady polskiej w Paryżu; tamże, Pismo kierownika Repatriacji Ambasady RP w Paryżu T. Oppmanna i attaché Ambasady RP w Paryżu W. Wierbłowskiej w sprawie reemigracji górników z Francji, Paryż, 11 XI 1946 r., k. 50.

${ }_{35}$ AAN, MZO, sygn. 836 ( $m f$ B-5957), Prośba Stanisława Bogdańskiego, repatrianta z Jedliny-Zdroju, Wałbrzych, b.d., k. 43; AAN, RNPwF, sygn. mf 1927/11, t. 95 (354/IV-95), Sprawozdanie S. Jakubowicza z 10-dniowej podróży do Katowic, Zabrza, Bytomia, Gliwic, Wałbrzych[a] i Wrocławia o sytuacji repatriantów z Francji, Warszawa, 5 XI 1946 r., k. 54. 
że polscy górnicy z Francji wyrażali głębokie rozczarowanie niskimi płacami, które wahały się (w zależności od stanowiska i zaszeregowania) od 5 do 15 tys. zł. Wyższe pensje osiagali tylko ci, którzy podejmowali pracę $\mathrm{w}$ nadgodzinach, często narażając swoje zdrowie ${ }^{36}$. Opinię tę potwierdza sprawozdanie Jeana Baelena, ówczesnego ambasadora Francji w Polsce. Przodownicy pracy mogli zarobić miesięcznie do 35 tys. zł. Baelen zaprzeczył jednocześnie doniesieniom polskiej prasy, jakoby przodownicy w górnictwie mogli zarobić miesięcznie od 41 do 98 tys. $z^{37}$. Pensje w wysokości $25-50$ tys. zł otrzymywali inżynierowie, kierownicy i dyrektorzy zakładów produkcyjnych i kopalń. Zdarzały się przypadki naliczania bardzo wysokich premii osobom zajmujacym kierownicze stanowiska (często wynoszących dziesięciokrotność przeciętnej pensji robotnika). Dyrektor Bytomskiego Zjednoczenia Przemysłu Węglowego (BZPW) oprócz premii zasadniczej i premii wydobycia pobierał dodatkowo premię indywidualną w wysokości 95 tys., a komisarz oszczędnościowy otrzymywał premię w wysokości 60-90 tys. w nagrodę za przeprowadzone oszczędności w zakładach produkcyjnych ${ }^{38}$. Takie dysproporcje $\mathrm{w}$ przyznawaniu pensji i premii, niepraktykowane we Francji, wywoływały oburzenie „francuskich" górników.

Górnicy narzekali również na jakość i ilość produktów spożywczych, które otrzymywali w ramach przydziału. W jednym z listów do „Narodowca" skonstatowano, że górnik we Francji nawet w czasie strajku „lepiej się odżywiał niż robotnik w kraju” ${ }^{39}$. Trudności z podstawowymi produktami spożywczymi pojawiły się jesienią $1946 \mathrm{r}$. Oficjalnie o brakach w dostawach żywności mówiono podczas konferencji, w której uczestniczyli reemigranci z Francji, wojewoda śląsko-dąbrowski gen. Aleksander Zawadzki oraz dyrektor Centralnego Zarządu Przemysłu Węglowego (CZPW) Fryderyk Topolski. Reemigranci skarżyli się na

${ }^{36}$ AMAE, Europe 1944-1960, Pologne 1944-1949, sygn. 70, Guy Monge, Consul de France à Wroclaw à Son Excellence Monsieur Robert Schuman Ministre des Affaires Étrangères, Direction d'Europe, Wroclaw, 15 XII 1948 r., k. 195-196

37 AMAE, Europe 1944-1960, Pologne 1944-1949, sygn. 68, Monsieur Jean Baelen Ambassadeur de la République Française à Varsovie à Monsieur le Ministre des Affaires Étrangères Europe, Communiqué à Affaires Économiques et Financières et à Information et Presse, Salaires et prix en Pologne, Varsovie, 13 VI 1949 r., k. 246-248.

38 Tamże, k. 246-247; AIPN, sygn. 01265/83, Raport miesięczny od 1 do 30 IV 1948 r. sporządzony przez WUBP w Katowicach dla ministra bezpieczeństwa publicznego gen. dyw. S. Radkiewicza w Warszawie, Katowice, 5 V 1948 r., k. 49-50 (numeracja pdf).

39 „P.”, „Straszna dola robotnika polskiego w kraju”, [List od siostry], „Narodowiec” 9 I 1949, s. 2. 
biedę, głodowe pensje, brak rent, złą jakość podstawowych produktów, opowiadali o rodzinach, które nawzajem wspomagały się w biedzie ${ }^{40}$. W raporcie Wojewódzkiego Urzędu Bezpieczeństwa Publicznego we Wrocławiu czytamy: „daje się zauważyć rozgoryczenie i niezadowolenie [brakiem produktów żywnościowych - A.N.] wśród górników, nawet wśród szczerych demokratów. Szczególne niezadowolenie przejawiaja górnicy reemigranci z Francji, wśród których jest szerzona propaganda, iż niesłusznie postapili wracając do Polski i wychwalająca [sic!] warunki we Francji”"

W 1949 r., równolegle z odebraniem kart żywnościowych, wprowadzono nowy system wynagrodzeń, których wysokość zależała od dziennej ilości wydobytego węgla. Uznano, że górnik jest w stanie wydobyć w ciagu dnia około 10-12 $\mathrm{m}^{3}$ węgla i za dniówkę płacono ok. $120 \mathrm{zł}$. Likwidacja kart żywnościowych i wprowadzenie nowego systemu wynagrodzeń, a w konsekwencji degradacja sytuacji materialnej rodzin, spowodowały w 1949 r. wybuch strajku w wałbrzyskich kopalniach. Jak się szybko okazało, protest potrwał jednak tylko godzinę, bo tyle czasu potrzebowały UB i Korpus Bezpieczeństwa Wewnętrznego, aby zaprowadzić „porządek”, aresztując inicjatorów strajku ${ }^{42}$.

Wbrew obietnicom władz, deklarujących zapewnienie dobrych warunków mieszkaniowych, rząd nie poradził sobie z kryzysem mieszkaniowym przez cały okres akcji reemigracyjnej ${ }^{43}$. Wystarczy przypomnieć, że na czas reemigracji w 1946 r. zakłady kopalniane na Górnym i Dolnym Śląsku dysponowały 230 tys. mieszkań, ale tylko 70 tys. z nich spełniało kryteria lokalu nadającego się do zamieszkania. W dodatku jedną trzecią $\mathrm{z}$ nich przyznano osobom niepracującym w górnictwie. $\mathrm{Z}$ powodu wielkiego deficytu mieszkań po wojnie to właśnie ich budowanie (głównie

${ }^{40}$ AAN, MZO, sygn. 836 (mf B-5957), Protokół konferencji odbytej 8 X 1946 r. w Zabrzu z przedstawicielami reemigrantów z Francji w obecności wojewody śląsko-dąbrowskiego i gen. dyrektora CZPW inż. Topolskiego, [8 X 1946 r.], k. 426-428.

${ }^{41}$ AIPN, sygn. 01265/2112, Raport Wydziału IV WUBP we Wrocławiu do dyrektora Departamentu IV MBP w Warszawie o sytuacji politycznej na obiektach obsługiwanych przez Wydział IV, Wrocław, 30 X 1948 r., k. 149.

${ }^{42}$ AMAE, Cabinet du Ministre, Cabinet R. Schuman 1948-1953, sygn. 53, Renseignement de contre-ingérence politique, Mouvements de grèves dans les mines polonaises formentés par des travailleurs rapatriés de France, source: bonne, 11 III 1949, 2 IV 1949 r., k. 165-166; AMAE, Europe 1944-1960, Pologne 1944-1949, sygn. 87, Note, a.s. mouvements de grèves dans les mines polonaises formentés par des travailleurs rapatriés de France, [b.d.], k. 199-200; D. Jarosz, Polacy a stalinizm 1948-1956, Warszawa 2000, s. 71-72.

${ }^{43}$ AAN, MZO, sygn. 835 (mf B-5955), Pismo dr. Z. Grątkowskiego (w zastępstwie naczelnego dyrektora administracyjnego CZPW) do Bytomskiego Zjednoczenia P[rzemysłu] W[ęlowego] w Bytomiu, Katowice, 10 VIII 1946 r., k. 224. 
tworzenie osiedli górniczych) od 1946 r. było najważniejszym zadaniem władz Górnego i Dolnego Ślaska. W planie trzyletnim uwzględniono budowę ponad 20 tys. mieszkań dla górników ${ }^{44}$.

Przygotowania do przyjazdu pierwszych reemigrantów z Francji na Górny i Dolny Śląsk rozpoczęto już na początku 1946 r. W zrujnowanym kraju taka skala potrzeb była dużym wyzwaniem. Zarządzono też powołanie komisji lokalowych, których zadanie miało polegać na kontroli najmu, w celu przeprowadzenia natychmiastowej akcji przydziału mieszkań „dla pracowników zakładów przemysłowych i innych zakładów pracy o znaczeniu państwowym lub gospodarczym”. Zapewnienie lokum dla pierwszego tysiąca rodzin wiązało się z eksmisją osób, których praca była niezwiąana $\mathrm{z}$ górnictwem. Do przeprowadzenia tej operacji upoważniono władze miast oraz $\mathrm{CZPW}^{45}$.

W pierwszych miesiącach akcji osiedleńczej reemigranci otrzymywali mieszkania po wyeksmitowanych $\mathrm{z}$ nich obywatelach niemieckich ${ }^{46}$. Józef Wesołowski - jeden z reemigrantów - wspominał, że gdy razem ze swoimi rodzicami wszedł do mieszkania, które dostali z przydziału, $\mathrm{w}$ kotle leżało jeszcze przygotowane do rozwieszenia pranie poprzednich lokatorów ${ }^{47}$.

Nie wszystkie mieszkania miały standard, który pozwalałby na natychmiastowe zamieszkanie. Wiele domów i lokali, np. w Wałbrzychu, wymagało gruntownego remontu. Dlatego części reemigrantów CZPW zaproponowało osiedlenie w Świebodzicach, miejscowości położonej $12 \mathrm{~km}$ od Wałbrzycha. Burmistrz Świebodzic zgodził się odstapić tysiąc mieszkań należących do stacjonującej tam Armii

${ }^{44}$ M. Rusiłło, Mieszkania dla górników, „Gazeta Polska” 19 X 1946, s. 4.

${ }_{45}$ AAN, MZO, sygn. 835a (mf B-5956), Pismo wojewody ślasko-dąbrowskiego gen. dyw. A. Zawadzkiego do Departamentu Osiedleńczego MZO w Warszawie w sprawie wprowadzenia publicznej kontroli najmu, powołania [komisji] lokalowych oraz przydzielenia mieszkań dla górników-reemigrantów powracających z Francji, Katowice, 16 IV 1946 r., k. 15-16; tamże, Pismo wojewody śląsko-dąbrowskiego gen. dyw. A. Zawadzkiego do starosty powiatowego jako przewodniczacego Wydziału Powiatowego dotyczace przygotowania mieszkań dla górników-reemigrantów z Francji, Katowice, 11 IV 1946 r., k. 45-46; tamże, Pismo wojewody śląsko-dąbrowskiego gen. dyw. A. Zawadzkiego do Oddziału Wojewódzkiego w Katowicach Tymczasowego Zarządu Państwowego, Katowice, 11 IV 1946 r., k. 47-48; Archiwum Instytutu Pamięci Narodowej Oddział w Katowicach (dalej: AIPN Ka), sygn. 74/2, t. 3, Raport sytuacyjny Komendanta Miasta MO w Zabrzu od 4 XI do 4 XII 1946 r. w myśl rozkazu Kom[endanta] Gł[ównego] MO nr 154 o sytuacji gospodarczej i nastrojów wśród ludności, Zabrze, 3 XII 1946 r., k. 73 (numeracja pdf).

${ }^{46}$ DSH, AHM, sygn. 1140, Relacja Zdzisława Cedlera; DSH, AHM, sygn. 1220, Relacja Aleksandra Jarczaka.

${ }^{47}$ P. Retecki, dz. cyt., s. 81. 
Czerwonej ${ }^{48}$. Wymagały one jednak gruntownego remontu, a przedsiębiorstwa kopalniane nie zawsze mogły go przeprowadzić. Z relacji Aleksandra Jarczaka i Jana Gallusa wynika, że w lokalach odebranych Armii Czerwonej remontu nie planowano, przydzielajac reemigrantom mieszkania i domy kompletnie zdewastowane. Za toaletę służyły wyrabane dziury w podłodze łazienek; w domach nie było ani mebli, ani materacy. Rodzina Gallusów przez dwa miesiace spała na podłodze ${ }^{49}$.

O skali lokalowego deficytu świadczy choćby sytuacja w Bytomiu, gdzie w 1946 r. BZPW uzyskało od władz miasta 456 mieszkań, a w 1947 r. zjednoczenie potrzebowało ok. 1400 mieszkań dla kolejnych przybyszy z Francji ${ }^{50}$. Uruchomienie kopalń spowodowało masowy przypływ ludności, której przedsiębiorstwa kopalniane nie były w stanie zapewnić lokali mieszkalnych. Starcia CZPW z władzami Bytomia o przydział lokali były na porządku dziennym, niejednokrotnie mieszkaniowe spory musiał rozstrzygać wojewoda śląski. Górnicza strona często zarzucała samorządowi miasta, że nie wywiąuje się z obietnic. Bardzo napięta sytuacja miała miejsce w połowie $1946 \mathrm{r}$., gdy CZPW spodziewało się transportów z 800 rodzinami „francuskich” reemigrantów. Kompromis udało się osiagnaç w czerwcu 1946 r., kiedy to CZPW otrzymało 150 domów dla górników z Francji ${ }^{51}$. Deficyt lokali odczuwały również Gliwice i Ruda Śląska. Poważnym problemem była dewastacja mieszkań i domów przez stacjonujących tam żołnierzy Armii Czerwonej52.

W 1947 r. rozpoczęto budowę osiedla górniczego w położonej kilka kilometrów od Gliwic Sośnicy. Na początku 1947 r. oddano tam 500 mieszkań. Ponadto władze miasta planowały eksmisję tzw. elementu słabego, czyli osób, które nie pracowały w przemyśle górniczym ${ }^{53}$.

${ }^{48}$ AAN, MZO, sygn. 835a (mf B-5956), Pismo dr. Z. Grątkowskiego (w zastępstwie naczelnego dyrektora administracyjnego CZPW) do generalnego pełnomocnika rządu do spraw repatriacji wiceministra ziem odzyskanych w Warszawie Władysława Wolskiego, Katowice, 25 II 1947 r., k. 152; AD PdC, sygn. 1 Z 463, nr 2861/II/OP, Note de renseignements, objet: a.s. du rapatriement des mineurs polonais, source: informateur, valeur: sûre, Béthune, 4 IX 1947 r., b.p.

${ }^{49}$ DSH, AHM, sygn. 1220, Relacja Aleksandra Jarczaka; DSH, AHM, sygn. 1138, Relacja Jana Gallusa.

50 AAN, MZO, sygn. 835 (mf B-5955), Notatka dla delegata MZO mgr. Sorbiana, Bytom, 13 III 1947 r., k. 107.

${ }^{51}$ Tamże, Memoriał CZPW w myśl uchwały powziętej na konferencji odbytej 19 VI [19]46 r., k. 13-14.

${ }^{52}$ Tamże, Departament Kontroli [MZO], Sprawozdanie z podróży służbowej, Warszawa, 26 IV 1946 r., k. 53.

53 Tamże, Protokół konferencji w sprawie dostarczania mieszkań dla górników repatriantów 12 V 1947 r. w gabinecie prezydenta miasta Koj. Obecni: wiceprezydent Kolasiński i Mikumicki, [12 V 1947 r.], k. 66-67. 
W momencie rozpoczęcia reemigracji wiosną 1946 r. złą sytuację mieszkaniową notowano również na Dolnym Śląsku. Ilość przygotowanych mieszkań jedynie w minimalnym stopniu zaspokajała potrzeby, szczególnie w perspektywie spodziewanego kolejnego transportu emigrantów z Francji, szacowanego na 3,1 tys. rodzin górniczych. W celu pozyskania wolnych lokali uciekano się do najróżniejszych środków, m.in. eksmisji osób pozostających bez pracy. Według słów delegata górników konieczność pozbawienia ludzi mieszkań usprawiedliwiano w ten sposób: ,jest w Wałbrzychu przeszło 20 tys. ludności niepracującej, najrozmaitszych spekulantów i szabrowników" ${ }^{54}$.

W 1947 r. najgorzej przedstawiała się sytuacja w Bytomiu, który w marcu potrzebował dla reemigrantów 1429 mieszkań. Ich brak niósł ryzyko niewykonania planu wydobycia węgla ${ }^{55}$. Sytuacja ta stała się obiektem krytyki ze strony „Narodowca”, na którego łamach wyśmiewano „szeroko zakrojoną akcję znalezienia 200 mieszkań” dla górników wracających z Francji. Ostatecznie część mieszkań udało się władzom zdobyć w rezultacie eksmisji „niegórników”. Uznano, że osoby pracujące w zawodach rzemieślniczych są mniej potrzebne miastu niż górnicy. Ofiarą swoistych rugów padli również pierwsi osiedleńcy z centralnej Polski ${ }^{56}$. Priorytety w przyznawaniu mieszkań górnikom i kierowanie się kluczem zawodowym każą zwrócić uwagę na jeszcze inny problem: jak trudne musiało być sasiedztwo górników-reemigrantów z rodakami, którzy właśnie przez nich stracili swoje mieszkania.

W ramach uzdrawiania sytuacji dyrekcje kopalń zdecydowały o sprowadzeniu „, zagranicy gotowych domów drewnianych”, tzw. domków fińskich $^{57}$. Pomysłodawcą transakcji wiazanej z Finlandią był Jan Mitręga, członek Związku Zawodowego Górników, późniejszy minister górnictwa i energetyki. Polska miała otrzymać 4 tys. domków fińskich w zamian za dostawy węgla do Finlandii ${ }^{58}$.

${ }^{54}$ AAN, MZO, sygn. 835a (mf B-5956), Sprawozdanie delegata górników z Francji Skórnoga, Wałbrzych, 17 V 1946 r., k. 37.

55 Tamże, Notatka dla delegata MZO mgr. Sorbiana, Bytom, 13 III 1947 r., k. $171-172$.

56 O mieszkaniach dla górników, „Narodowiec” 22 IV 1947, s. 3.

${ }^{57} 8$ tysięcy nowych mieszkań dla górników, „Gazeta Polska” 28 III 1947, s. 3; A. Krzemień, dz. cyt., s. 142; AAN, Ministerstwo Odbudowy, sygn. 469, Projekt uchwały Komitetu Ekonomicznego Rady Ministrów w sprawie pokrycia należności za dostarczane dla przemysłu węglowego domki z Finlandii (otrzymuja: Ministerstwo Skarbu, Ministerstwo Przemysłu i Handlu, Centralny Urząd Planowania, Biuro Rozrachunków Międzynarodowych), b.d., k. 56.

58 AAN, MZO, sygn. 836 (mf B-5957), Protokół zebrania odbytego w sali Zarządu Miejskiego 13 III $1947 \mathrm{r}$. w sprawie rozwiązania problemu mieszkaniowego na terenie Bytomia dla górników-reemigrantów z Francji, [13 III 1947 r.], k. 449. 
Tymczasem informacje zawarte $\mathrm{w}$ dokumentach zgromadzonych w archiwach nie pozostawiają wątpliwości, że standard mieszkań budził watpliwości nie tylko w pierwszym okresie reemigracji, ale także w kolejnych latach. Większość górników była rozczarowana lokalami, które im przydzielono. Uważali, że sa zbyt małe, za ciasne $^{59}$. Wielu reemigrantom przyznawano mieszkania jednopokojowe, jedynie $\mathrm{z}$ obietnica przydziału lokum o większym metrażu ${ }^{60}$.

Permanentną irytację górników budziła sprawa przydziału mebli: poszczególne sprzęty przyznawano na podstawie dokładnych list inwentarzowych z imieniem i nazwiskiem górnika, który meble otrzy$\mathrm{mał}^{61}$. Mimo to wyposażenie lokali od początku pozostawiało wiele do życzenia. Ciagle brakowało łóżek, szaf, stołów, krzeseł, kredensów kuchennych, umywalek, itp. ${ }^{62}$ Przed spodziewanym transportem górników-reemigrantów prowadzona była goraczkowa akcja zbierania i poszukiwania mebli do mieszkań, często ze słabym skutkiem. Jeśli reemigrantom nie można było zapewnić łóżek, do domów wnoszono materace ${ }^{63}$.

Osiedlanie reemigrantów w mieszkaniach o małym metrażu potwierdza również raport sporządzony przez kierownika Wydziału Repatriacyjnego Ambasady RP w Paryżu Tadeusza Oppmanna i Wandę

${ }^{59}$ Jak instaluja się $w$ Kraju górnicy polscy z Francji. Wywiad z prezesem RNPF, ob. Józefem Łuka, po powrocie z Polski, „Gazeta Polska” 3 VIII 1946, s. 1.

${ }^{60}$ W.S. Wałbrzych, Jak żyja reemigranci z Francji w Wałbrzychu (Korespondencja $z$ Kraju), „Gazeta Polska” 6 VII 1950, s. 3.

${ }_{61}$ AAN, MZO, sygn. 835 (mf B-5955), Pismo kierownika Biura Obwodowego O[kręgowego] U[rzędu] L[ikwidacyjnego] (w zastępstwie mgr. Adamczyka dyrektora Tymczasowego Zarządu Powiatowego w Bytomiu) do delegata MZO w Warszawie, Bytom, 10 VIII 1948 r., k. 35; tamże, Pismo kierownika Biura Obwodowego O[kręgowego] U[rzędu] L[ikwidacyjnego] (w zastępstwie mgr. Adamczyka dyrektora Tymczasowego Zarządu Powiatowego w Bytomiu) do BZPW w Bytomiu, Bytom, 10 VIII 1946 r., k. 36; tamże, Pismo wicedyrektora O[kręgowego] U[rzędu] L[ikwidacyjnego] w Katowicach mgr. Z. Brokla (w zastępstwie dyrektora O[kręgowego] U[rzędu] L[ikwidacyjnego] w Katowicach) do BZPW w Bytomiu, Katowice, 22 VIII 1946 r., k. 47; tamże, Pismo dyrektora BZPW w Bytomiu inż. E. Sękiewicza do O[kręgowego] U[rzędu] L[ikwidacyjnego], 19 VIII 1946 r., k. 48.

${ }_{62}$ Tamże, Sprawozdanie z przyjęcia transportu repatr[iantów] górników z Francji dla delegata MZO mgr. Sorbiana, Ruda Śl[aska], 23 X 1946 r., k. 271-272.

${ }^{63}$ AAN, MZO, sygn. 835a (mf B-5956), Pismo dyrektor Departamentu Osiedleńczego MZO w Warszawie W. Lechowicza do [Zabrzańskiego] Zjednoczenia Węglowego w Zabrzu w sprawie przydziału mebli dla repatriantów górników z Francji zatrudnionych w przemyśle węglowym, Warszawa, 9 X 1946 r., k. 110; tamże, Pismo dyrektora Departamentu Likwidacyjnego MZO w Warszawie W. Bukowskiego do Okręowego Urzędu Likwidacyjnego we Wrocławiu, Warszawa, 25 X 1946 r., k. 117; tamże, Pismo [Zabrzańskiego] Zjednoczenia Przemysłu Węglowego w Zabrzu do Departamentu Osiedleńczego MZO w Warszawie, 27 VIII 1948 r., k. 116. 
Wierbłowska, która pełniła funkcję attaché ambasady polskiej w Paryżu. Wynika z niego, że pierwszym reemigrantom przydzielano głównie mieszkania jednopokojowe. Były nawet przypadki osiedlania rodzin reemigrantów w barakach. Potwierdza się też fakt, że najgorsza sytuacja mieszkaniowa była w Zagłębiu Bytomskim ${ }^{64}$.

Akcja reemigracyjna udowodniła, że założenia polskiej polityki remigracyjnej od początku nie były spójne. W trakcie realizacji umów remigracyjnych rozmijały się propagandowe założenia polityczne, potrzeby gospodarcze (utrzymanie tempa wydobycia węgla i reemigracja fachowych górników) oraz możliwości mieszkaniowe. Trzeba też podkreślić, że władze miast miały kłopoty z zapewnieniem reemigrantom przyzwoitych warunków mieszkaniowych nawet w okresie 1947-1948, kiedy do Polski powróciło znacznie mniej górniczych rodzin niż zadeklarowano w umowach.

Rolnicy byli druga grupa zawodowa, na powrocie której zależało władzom warszawskim. Trudno stwierdzić na podstawie uboższej dla tej grupy zawodowej bazy źródłowej, czy utyskiwania rolników na warunki mieszkaniowe i materialne były równie częste jak w przypadku rodzin górniczych. Wydaje się raczej, że dysproporcja między warunkami we Francji a tymi, które mieli w Polsce, nie była tak mocno odczuwalna jak w przypadku górników. Robotnicy rolni byli tą grupa zawodowa, która decydując się na przeprowadzkę do Polski, nie miała - w sensie materialnym - tyle do stracenia co górnicy. Głosy niezadowolenia były słyszalne coraz częściej po rozpoczęciu kolektywizacji, we wrześniu $1948 \mathrm{r} \cdot{ }^{65}$ To właśnie obawa przed nią zatrzymała rolników we Francji po 1948 r. Niechęć do osadnictwa spółdzielczo-parcelacyjnego, a potem funkcjonowania spółdzielni produkcyjnych potwierdza również Franciszek Kusiak. Według jego badań nad osadnictwem na Ziemiach Zachodnich i Północnych częste osiedlanie reemigrantów w ramach osadnictwa spółdzielczo-parcelacyjnego nie należało traktować $\mathrm{w}$ kategoriach ich poparcia dla tej formy gospodarowania, ale wprost przeciwnie, jako etap poprzedzający wyodrębnienie indywidualnych gospodarstw rolnych ${ }^{66}$.

${ }^{64}$ AAN, MZO, sygn. 836 ( $m f$ B-5957), Pismo attaché Ambasady RP w Paryżu W. Wierbłowskiej i kierownika Repatriacji Ambasady RP w Paryżu T. Oppmanna w sprawie reemigracji górników z Francji, Paryż, 11 XI 1946 r., k. 49; AAN, MZO, sygn. 835 (mf B-5955), [Raport], Bytom, 17 VI 1947 r., k. 158.

${ }^{65} \mathrm{O}$ kolektywizacji rolnictwa w Polsce zob. m.in. D. Jarosz, Polityka władz komunistycznych $w$ Polsce $w$ latach 1948-1956 a chtopi, Warszawa 1998; tenże, Polacy a stalinizm..., s. 11-60.

${ }^{66}$ F. Kusiak, Reemigracja polska po drugiej wojnie światowej. Udział $w$ zasiedlaniu ziem zachodnich i pótnocnych, Wrocław 1995, s. 52. 


\section{Obyczaje, postawy i zachowania reemigrantów}

Osiedla, w których umieszczono górnicze rodziny w Wałbrzychu (tam była największa koncentracja reemigrantów), miały charakter skupisk zwartych, na kształt tych, w jakich górnicy mieszkali na północy Francji. Był to rodzaj przestrzeni zamkniętej, autonomicznej, determinującej określone postawy i zachowania. Tymczasem miejsca pracy górników - kopalnie - były środowiskiem, w którym zderzały się ze sobą różne narodowości i kultury, Wałbrzych był bowiem mieszanka różnych grup społecznych, a także osiedleńców, przesiedleńców z Polski centralnej i Kresów Wschodnich. Taka sytuacja generowała dwa typy postaw: tolerancji dla odmienności albo odrzucenia. W Wałbrzychu „francuscy” górnicy od początku nie mogli liczyć na akceptację środowiska, co pogłębiło ich wzajemne więzi, zadzierzgnięte jeszcze we Francji.

Reemigranci wrócili do Polski nie tylko z dobytkiem, ale z własnymi doświadczeniami: przywieźli ze sobą także określony styl życia i obyczaje, z którymi nie zamierzali się rozstawać, m.in. zwyczaj gry $\mathrm{w}$ pétanque (w Polsce określana jako bule $-\mathrm{z}$ franc. boule). Zwyczaj spędzania czasu w gronie rodziny, sąsiadów lub znajomych był swego rodzaju rytuałem. „Francuscy” górnicy nie czuli potrzeby szukania nowego towarzystwa, co mogło sprawiać wrażenie, że czuli się lepsi od otaczajacego ich środowiska. Zdaniem Piotra Reteckiego izolacjonizm „Francuzów” mógł wynikać z tego, że pracowali w tych samych kopalniach, tzn. sąsiedzi z osiedla spotykali się również w pracy ${ }^{67}$. Stąd można wysnuć wniosek, że obok wspomnianych wyżej zachowań „,bezpośrednich”, kreowanych wskutek kontaktów z Polakami z Francji, istniały i te „pośrednie”, oparte na powielanych opiniach (prawdziwych lub nieprawdziwych) o „Francuzach”, które wynikały przede wszystkim z niechęci reemigrantów do kontaktu z innymi środowiskami.

Górnicy z Francji, jako pracownicy wysoko wykwalifikowani, w przeciwieństwie do przybyszów z Polski centralnej oraz repatriantów „zza Buga”, byli w polskich kopalniach elita, uchodzili za najlepszych specjalistów. Dlatego zatrudniano ich m.in. na stanowiskach rębaczy i strzałowych. Kopalnie wałbrzyskie, gdzie wydobywano wysokogatunkowy węgiel koksujący, priorytetowy dla polskiej gospodarki, były na specjalnych prawach, bo ten węgiel był również najważniejszym polskim produktem eksportowym.

Górnictwo potrzebowało dobrych wzorców, etosu pracownika. Stał się nim np. osiadły w Zabrzu reemigrant z Belgii Wincenty Pstrowski,

${ }^{67}$ W. Markiewicz, dz. cyt., s. 167-171; P. Retecki, dz. cyt., s. 77. 
którego słynne zawołanie: „Kto wyrąbie więcej co ja?” stało się początkiem współzawodnictwa pracy: 17 XI 1947 r. CZPW powołało do życia komitety współzawodnictwa pracy ${ }^{68}$. Jak się jednak okazało, zwolenników socjalistycznej idei współzawodnictwa wśród „francuskich” górników, mimo powielanej tezy, że reprezentowali najliczniejsza grupę przodowników, nie było wielu. Przodownicy, nazywani „wyścigaczami”, nie mogli liczyć na uznanie pozostałych kolegów. „Francuzi”, przyzwyczajeni do wolnych niedziel, nie mogli pogodzić się z peerelowska praktyka zmuszania ich do pracy w dzień wolny. Ten nakaz stał się zreszta przyczyną rozwieszania w kopalniach różnej treści ulotek: „Pora z tym skończyć - w niedzielę pracować, nie będziemy dłużej tolerować komunistycznej partii, która służy Gaulajterowi Stalinowi, chcemy pracować 8 godzin, a nie 9 godzin. Polscy górnicy łączcie się!". Opór przeciwko współzawodnictwu pracy wynikał nie tylko z lęku przed wymuszeniem znacznie większego wysiłku, ale również z powodów ekonomicznych. Współzawodnictwo doprowadzało do marnotrawienia surowców, niszczenia maszyn, a także obniżania jakości produkowanych towarów ${ }^{69}$. O wyraźnej niechęci do współzawodnictwa pracy świadczyła reakcja reemigrantów na śmierć Pstrowskiego w maju 1948 r., mówili oni między soba: „Pracuj jak Pstrowski - zdechniesz jak Pstrowski” lub „Dobrze, że go już cholera wzięła. Węgiel jednak twardszy od niego"70.

W pracy „Francuzi”, mimo niekwestionowanych wysokich kwalifikacji, mieli opinię trudnych we współżyciu. Przyzwyczajeni do francuskiej „wolności” i swobody w wyrażaniu poglądów, narzekali, że byli pilnowani przez swoich bezpośrednich przełożonych. Z kolei górnicy z innych rejonów Polski uważali, że „Francuzi” traktowali innych z poczuciem wyższości. Takie postrzeganie miało przyczyny w odwadze mówienia tego,

${ }^{68}$ W. Markiewicz, dz. cyt., s. 171-172; A. Frużyński, Kopalnie wegla kamiennego $w$ Polsce, Łódź 2012, s. 36-38; o roli współzawodnictwa pracy zob. m.in. Współzawodnictwo pracy $w \dot{z} y c i u$ gospodarczym, społeczno-politycznym i propagandzie PRL, red. B. Tracz, Katowice 2008.

${ }^{69}$ AIPN, sygn. 01265/2115, Sprawozdanie miesięczne od 1 I do 1 II 1951 r. WUBP we Wrocławiu do dyrektora Departamentu IV MBP w Warszawie, Wrocław, 1 II 1951 r., k. 592; tamże, Sprawozdanie miesięczne od 1 II do 1 III 1951 r. WUBP we Wrocławiu do dyrektora Departamentu IV MBP w Warszawie, Wrocław, 2 III 1951 r., k. 541; A. Frużyński, dz. cyt., s. 36-38; J. Chumiński, Wptyw socjalistycznego współzawodnictwa pracy na stosunek środowiska robotniczego do obowiazków pracowniczych 1945-1956, w: Wspótzawodnictwo pracy $w$ życiu gospodarczym..., s. 40.

70 AIPN, sygn. 01265/83, Raport miesięczny od 1 do 30 IV 1948 r. sporządzony przez WUBP w Katowicach do ministra bezpieczeństwa publicznego w Warszawie gen. dyw. S. Radkiewicza, Katowice, 5 V 1948 r., k. 50 (numeracja pdf); J. Chumiński, Wpływ socjalistycznego wspótzawodnictwa pracy..., s. 38-39. 
co myśla, np. na temat organizacji pracy, która ich zdaniem pozostawiała wiele do życzenia. Stałym powodem narzekań były także niskie pensje i praktyki oszukiwania przy przyznawaniu wynagrodzeń.

Górnicy i robotnicy skarżyli się także na złe ich traktowanie przez administrację polskich kopalń i hut ${ }^{71}$. Taka postawa umacniała reemigrantów w przekonaniu, że decyzja o powrocie do kraju była pochopna. Żałował jej np. ojciec Jana Gallusa, który często powtarzał synowi, że czuł się w pracy niedoceniany, a nawet szykanowany, i z tego powodu postanowił przejść na emeryturę ${ }^{72}$. Na złe traktowanie narzekał również ojciec Jana Smolarza, skarżąc się w domu, że sztygar w polskiej kopalni ubliżał Polakom (w tym również i reemigrantom), nazywając ich „polskimi świniami” i „nierobami”73. Opinie te znajdują również potwierdzenie w sprawozdaniu Feliksa Chiczewskiego dla polskiego MSZ z czerwca $1947 \mathrm{r.}^{74}$

Górnicy krytykowali również system obsadzania stanowisk kierowniczych. Nie rozumieli ciagłych zmian kadrowych, uważając taką sytuację za wysoce niemoralna. We Francji zdarzało się im przepracować nawet 20 lat pod kierownictwem tego samego dyrektora bądź naczelnego inżyniera. Sytuacja w Polsce była pod tym względem skrajnie odmienna. Rotacja na stanowiskach następowała co 3-4 lata i wiązała się również ze zmianami na niższych szczeblach, będąc przyczyną ogólnego zamieszania i chaosu. Górnicy uważali, że kadra, która ciągle „siedzi na walizkach”, nie może cieszyć się autorytetem i zaufaniem pracowników ${ }^{75}$.

Górnicy przyzwyczajeni do systemu francuskiego, gdzie gospodarka nie podlegała naciskom politycznym i ideologicznym, krytykowali nieustanną rotację wynikająca ze stalinowskiego systemu pracy. W $1949 \mathrm{r}$. wśród 828 osób zatrudnionych w CZPW 576 osób było podejrzanych o „wrogą działalność"76.

${ }^{71}$ AAN, MZO, sygn. 69 (mf B-5171), Protokół zebrania odbytego w Delegaturze na Francję Generalnego Pełnomocnika Rządu RP do Spraw Repatriacji 14 VIII 1947 r. z udziałem przedstawicieli Centralnego Zarządu Przemysłu Węglowego, [14 VIII 1947 r.], k. 77.

72 DSH, AHM, sygn. 1138, Relacja Jana Gallusa.

${ }^{73}$ P. Retecki, dz. cyt., s. 72.

${ }^{74}$ AAN, Generalny Pełnomocnik Rządu RP ds. Repatriacji, sygn. 195, Pismo konsula generalnego RP w Lille F. Chiczewskiego do Biura Konsularnego MSZ w Warszawie w sprawie reemigracji górników i robotników różnych zawodów (otrzymuja: Ambasada RP w Paryżu, delegat na Francję pełnomocnik rządu do spraw repatriacji), Lille, 15 VI 1947 r., k. 29.

75 W. Markiewicz, dz. cyt., s. 217, 219.

${ }^{76}$ J. Chumiński, Wptyw aparatu bezpieczeństwa..., s. 24. 
Źródłem codziennej niechęci do „Francuzów” oraz przyczyną konfliktów między nimi a innymi grupami Polaków była też obyczajowość reemigrantów, wyróżniających się na tle społeczności Górnego i Dolnego Śląska (głównie pochodzących z centralnej Polski i Kresów Wschodnich) powierzchownościa, manierami, starannością ubioru. „Francuzi” wyraźnie podkreślali swoją odrębność, np. piciem kawy (wówczas zwyczaj ten nie był w Polsce powszechny).

Konfrontacja społeczności „francuskiej” z pozostałymi mieszkańcami miała miejsce także na poziomach ideologicznym i religijnym. Negatywne nastawienie do reemigrantów wynikało z coraz wyraźniejszych postaw antysowieckich, a także rosnacego wpływu Kościoła katolickiego w polskim społeczeństwie. Polacy okazywali wrogość „francuskim” górnikom np. z powodu tego, że ci nie zapisywali dzieci na lekcje religii. „Francuzi” z kolei krytykowali osobliwe zwyczaje kresowian, którzy dewastowali mieszkania, hodując w nich np. trzodę chlewną i drób ${ }^{77}$. Nie ulega wątpliwości, że na pogłębienie izolacjonizmu reemigrantów miało wpływ ich podejście do religii. Wprawdzie katolicyzm Polaków we Francji zdecydowanie wyróżniał ich na tle neutralności religijnej Francuzów, ale po przyjeździe do kraju uważali oni polską religijność za przejaw fanatyzmu religijnego i surowej krytyce poddawali zarówno obrzędowość mszy (np. częste klękanie w trakcie nabożeństw), jak i homilie księży ${ }^{78}$.

Spostrzeżenia te znajduja potwierdzenie w raporcie prefekturalnym z Archiwum Departamentalnego Pas-de-Calais. Według niego polski katolicyzm polegał głównie na godzeniu się na cierpienie, regularnym uczęszczaniu do kościoła i cierpliwym znoszeniu niedogodności życia. Najważniejszą intencją modlitw Polaków była chęć wyswobodzenia się spod okupacji sowieckiej, nawet za cenę kolejnej wojny między blokami wschodnim i zachodnim ${ }^{79}$. Nie oznaczało to bynajmniej, że „francuscy” Polacy byli ateistami; uważali tylko, podobnie jak zdecydowana większość Francuzów we Francji, że wiara jest prywatną sprawą każdego człowieka ${ }^{80}$.

77 AMSZ, z. 22, w. 3, t. 61, Pismo W. Wierbłowskiej attaché ambasady i T. Oppmanna kierownika repatriacji w Ambasadzie RP w Paryżu w sprawie reemigracji górników z Francji, Paryż, 11 XI 1946 r., k. 2; AMSZ, z. 22, w. 3, t. 59, Pro Memoria Biura do Spraw Repatriacji MSZ w Warszawie, Warszawa, 22 XI 1946 r., k. 7; W. Markiewicz, dz. cyt., s. 175; D. Jarosz, Mieszkanie sie należy... Studium z peerelowskich praktyk społecznych, Warszawa 2010, s. 28; A. Małkiewicz, dz. cyt., s. 81.

${ }^{78}$ W. Markiewicz, dz. cyt., s. 235; P. Retecki, dz. cyt., s. 78-79.

79 AD PdC, sygn. 1 Z 1087, nr 1192 SE, Objet: a.s. situation actuelle de la Pologne, source: sondages, valeur: sûre, Lens, 5 VI 1947 r., b.p; AD PdC, sygn. M 3237, nr 1192 SE, Objet: a.s. situation actuelle de la Pologne, source: sondages, valeur: sûre, Lens, 5 VI 1947, b.p.

${ }^{80}$ W. Markiewicz, dz. cyt., s. 235; P. Retecki, dz. cyt., s. 78-79. 
Antagonizmy między „kresowianami” a „Francuzami” nasilały się również z powodów politycznych, głównie dlatego, ci drudzy - nieświadomi siły rażenia „czerwonej” ideologii - akceptowali komunizm (nie postrzegali go jako systemu totalitarnego, lecz - jak we Francji - jako część systemu demokratycznego), natomiast repatrianci ze Wschodu, doświadczeni komunizmem, sceptycznie odnosili się do ustroju Polski Ludowej ${ }^{81}$. Z powodu ideologicznego zaangażowania $\mathrm{w}$ budowę nowego systemu (m.in. przynależność do PZPR, praca w MO i UB) repatrianci „zza Buga” nazywali „Francuzów” komunistami i bolszewikami ${ }^{82}$.

Źródłem antagonizmów było też środowisko dzieci i młodzieży reemigrantów urodzone we Francji. Informator „Sawa” donosił, że pracę w Polsce traktowali oni jako „zło konieczne”, myśląc o powrocie do Francji. Ponieważ na co dzień używali języka francuskiego, z trudem porozumiewali się z Polakami i czuli się tu „wyobcowani”"83. Dzieci reemigrantów miały duże kłopoty z przystosowaniem się do realiów polskiej szkoły. Powodem była nie tylko niewystarczająca znajomość języka polskiego, ale też brak wyrozumiałości ze strony kadry nauczycielskiej, pedagogicznej, a także kolegów. „Nie byłem w stanie powiedzieć trzech słów” - skarżył się jeden z uczniów-reemigrantów. Inna uczennica poczuła się dotknięta uwagą nauczyciela, który powiedział: „Nie jesteś we Francji!”, kiedy napisała $\mathrm{w}$ alfabecie polskim litere „, $\mathrm{q}^{\text {"84. }}$. Młode pokolenie w polskim środowisku mówiło po polsku z mocnym, francuskim akcentem, między sobą porozumiewali się najczęściej po francusku bądź polsko-francuskim żargonem, co bardzo drażniło polską społeczność. Były przypadki, kiedy reemigrantom z Francji w kategoryczny sposób zwracano

${ }^{81}$ W. Markiewicz, dz. cyt., s. 160; P. Retecki, dz. cyt., s. 76-77; AIPN Ka, sygn. 74/2, t. 3, Raport sytuacyjny Komendanta Miasta MO w Zabrzu od 4 XI do 4 XII 1946 r. w myśl rozkazu Kom[endanta] Gł[ównego] MO nr 154 o sytuacji gospodarczej i nastrojów wśród ludności, Zabrze, 3 XII 1946 r., k. 72 (numeracja pdf); tamże, Raport sytuacyjny Komendanta Miasta MO w Zabrzu od 5 VII do 5 VIII 1946 r. w myśl rozkazu nr 154 K[omendanta] Gł[ównego] MO wzór nr 1 o sytuacji politycznej, Zabrze, 5 VIII 1946 r., k. 38 (numeracja pdf).

${ }^{82}$ W. Markiewicz, dz. cyt., s. 173; P. Retecki, dz. cyt., s. 77; AIPN, sygn. 01355/69, Wykaz pracowników repatriantów z Francji, Miechowice, 19 VIII 1951, k. 18-25 (numeracja pdf); tamże, Wykaz reemigrantów [w] kopalni „Mikulczyce” w zjedn[oczeniu zabrzańskim], b.d., k. 33-37 (numeracja pdf); tamże, Wykaz reemigrantów z Francji oraz z Belgii [kopalnia „Rozbark”], kierownik Referatu Ochrony Przemysłowej kopalni „Rozbark”, C. Pietruszewski, Bytom, 7 VI 1951 r., k. 50-52 (numeracja pdf).

${ }^{83}$ AIPN Wr, sygn. 053/357 t. 1, Raport dekadowy od 15 do 26 III 1947 r., sprawozdanie ze stanu sieci agenturalno-informacyjnej [w nim informacja źródła „Sawa” z 18 III 1947 r.], k. 147.

${ }^{84}$ P. Retecki, dz. cyt., s. 75. 
uwagę, aby w Polsce nie porozumiewali się po francusku ${ }^{85}$. O niechęci mieszkańców Dolnego Śląska do reemigrantów (głównie młodzieży), ich złośliwości z powodu porozumiewania się na ulicy po francusku lub słabej znajomości języka polskiego pisał również Feliks Chiczewski i radca spraw społecznych Roman Dudziński w sprawozdaniu dla polskiego $\mathrm{MSZ}^{86}$.

Od „lokalnych” Polaków młodzi reemigranci wyróżniali się stylem ubierania, szykiem, jakością ubioru. Uwagę zwracała nie tylko płeć piękna, ale także młodzi mężczyźni i chłopcy, w charakterystycznych beretach, szalikach, marynarkach. Polacy nierzadko z zazdrością mówili o nich, że „noszą się z francuska” ${ }^{87}$.

\section{Pod okiem Urzędu Bezpieczeństwa}

Repatrianci i reemigranci, którym przyszło się zmagać z trudnościami materialnymi i uciążliwymi warunkami pracy, dodatkowo poddani zostali inwigilacji przez UB i jego jednostki terenowe, która stała w zasadniczej sprzeczności z propagandowymi hasłami komunistycznych władz polskich, wzywającymi do powrotu do ojczyzny.

Od początku zakrojona z rozmachem akcja była dowodem, że reemigrantów traktowano jako element obcy i wrogi. Głównym obiektem „zainteresowania” UB byli żołnierze Polskich Sił Zbrojnych oraz przybywajacy z Europy Zachodniej polscy robotnicy i górnicy, którzy z zasady podejrzewani byli o prowadzenie działalności szpiegowskiej na rzecz „państw imperialistycznych".

Intensyfikacja walki z rzekomo działajacymi w Polsce domniemanymi „siatkami szpiegowskimi” nastapiła w 1949 r., kiedy podczas obrad II Plenum KC PZPR Bierut zapowiedział walkę z obca agentura w szeregach partii i w gałęziach gospodarki. W myśl referatu wygłoszonego przez niego podczas III Plenum KC PZPR konieczne było utrzymanie „czujności” wobec

${ }^{85}$ Tamże; AAN, RNPwF, sygn. mf 1927/11, t. 95 (354/IV-95), Serge Karsky, En Pologne chez les Polonais de France. Les jeunes sont trop habitués à notre pays pour pouvoir s'acclimater, „La Voix du Nord”, 15 VI 1947 r., k. 66.

${ }^{86}$ AAN, Generalny Pełnomocnik Rządu RP ds. Repatriacji, sygn. 195, Pismo konsula generalnego RP w Lille F. Chiczewskiego do Biura Konsularnego MSZ w Warszawie w sprawie reemigracji górników i robotników różnych zawodów (otrzymuja: Ambasada RP w Paryżu, delegat na Francję pełnomocnik rządu do spraw repatriacji), Lille, 15 VI 1947 r., k. 29; AAN, Generalny Pełnomocnik Rządu RP ds. Repatriacji, sygn. 195 cz. 2, Pismo radcy do spraw społecznych R. Dudzińskiego do dyr. Żebrowskiego w MSZ w Warszawie, Paryż, 21 VI 1947 r., k. 15.

${ }^{87}$ P. Retecki, dz. cyt., s. 75. 
„szpiegów”, od najniższych szczebli partyjnych ${ }^{88}$. Po aresztowaniu André Simona Robineau w listopadzie 1949 r., tuz po posiedzeniu III Plenum KC PZPR, pierwszymi podejrzanymi o kontakty z obcym wywiadem stali się reemigranci z Francji. Za powód oskarżenia o współpracę z francuskim wywiadem uznawano już sam fakt posiadania rodziny we Francji oraz utrzymywanie listownych kontaktów. Wyrażanie sympatii w stosunku do „drugiej ojczyzny” traktowane było jako popieranie systemu „zgniłego Zachodu”. W okresie panujacej w Polsce „szpiegomanii” każdy kontakt z bliskimi bądź znajomymi z Francji traktowany był jak przejaw „zdrady” i „,szpiegostwa” ${ }^{\text {. }}$ Reemigranci utrzymujaccy kontakty $\mathrm{z}$ osobami mieszkajacymi w krajach Europy Zachodniej automatycznie podejrzewani byli o dokonywanie sabotażu w kopalniach, celowe zaniżanie produkcji, utrudnianie pracy, „wrogą działalność" i stawali się obiektami agenturalnego rozpoznania ${ }^{90}$.

Szczególne zainteresowanie resortu UB skupiło się na Ziemiach Odzyskanych, gdzie znajdowało się najwięcej zakładów pracy, w których zatrudniano reemigrantów z Zachodu. Kontrola obiektów gospodarczych i przemysłowych leżała w kompetencji Departamentu IV MBP (a obiektów terenowych - wydziałów IV WUBP ${ }^{91}$.

Fali „dywersji i sabotażu” w sektorze gospodarczym miało zapobiegać intensywne pozyskiwanie „informatorów”. W środowisku reemigrantów agentów rekrutowano głównie spośród „Francuzów” lub osób z nimi zaprzyjaźnionych. Pozyskani przekazywali urzędom bezpieczeństwa informacje o nastrojach panujących w ich środowisku. Z szacunków

${ }^{88}$ D. Jarosz, M. Pasztor, dz. cyt., s. 140-141.

89 W. Markiewicz, dz. cyt., s. 181; Archiwum Instytutu Pamięci Narodowej Oddział w Krakowie, sygn. 075/165, Meldunek o wszczęciu rozpracowania obiektowego dla naczelnika Wydziału I WUBP w Krakowie, Wadowice, 2 VII 1949 r., k.24.

${ }^{90}$ AIPN, sygn. 01265/2113, Raport o sytuacji politycznej na obiektach Wydziału IV od 25 V do 25 VI 1949 r. sporządzony przez szefa WUBP we Wrocławiu dla dyrektora Departamentu IV MBP w Warszawie, Wrocław, 30 VI 1949 r., k. 188-189; tamże, Raport o sytuacji politycznej na obiektach Wydziału IV od 25 II do 25 III 1949 r. sporządzony przez szefa WUBP we Wrocławiu dla dyrektora Departamentu IV MBP w Warszawie, Wrocław, 31 III 1948 r., k. 151; AIPN, sygn. 01265/2115, Sprawozdanie miesięczne od 1 I do 1 II 1951 r. WUBP we Wrocławiu do dyrektora Departamentu IV MBP w Warszawie, Wrocław, 1 II 1951 r., k. 590-591.

${ }^{91}$ Departament IV MBP wyłoniony został w 1945 r. z Wydziału IV Departamentu I MBP, który miał w swoich kompetencjach ochronę sektora gospodarczego. W styczniu 1953 r. kompetencje Departamentu IV MBP, zajmującego się zagadnieniami przemysłu ciężkiego, przejał nowo utworzony Departament IX MBP, który jednak po roku został zlikwidowany, a jego kompetencje z powrotem przekazano Departamentowi IV MBP; J. Chumiński, Wptyw aparatu bezpieczeństwa..., s. 20; Z. Nawrocki, Struktura aparatu bezpieczeństwa, w: Aparat bezpieczeństwa w Polsce. Kadra kierownicza, t. 1: 1944-1956, red. K. Szwagrzyk, Warszawa 2005, s. 26, 32, 34. 
wynika, że w 1948 r. na współpracowników w sektorze górniczym donosiło 1038 osób. W 1951 r. liczba informatorów wzrosła niemal czterokrotnie: służby zarejestrowały już 4082 osoby. UB nakłaniała do współpracy najczęściej osoby pełniące funkcje kierownicze, ze względu na posiadane przez nie informacje, które potem wykorzystywano w pracy operacyjnej ${ }^{92}$. Dokładna obserwacja reemigrantów „francuskich” prowadzona była dzięki obecności funkcjonariuszy bądź agentów UB w działach kadrowych i zakładach pracy ${ }^{93}$, jak w przypadku Kopalni Węgla Brunatnego w Turoszowie, gdzie w 1948 r. szczegółowej analizie poddano życiorysy reemigrantów z Francji i Belgii zatrudnionych na stanowiskach kierowniczych ${ }^{94}$. Zakrojona na szeroką skalę inwigilacja nie zawsze jednak przynosiła oczekiwane rezultaty. Informatorzy często byli werbowani przez UB metodą szantażu i z wykorzystaniem kompromitujących materiałów. Zdarzało się, że informacje pozyskane od takich osób nie przedstawiały „wartości operacyjnej” i zostały zakwalifikowane przez funkcjonariuszy jako niewystarczające. Cenne raporty zawdzięczano agentom wywodzacym się ze środowiska reemigrantów, ale zwerbowanym na zasadzie dobrowolności ${ }^{95}$.

Obraz sytuacji wyłaniajacy się z raportów agentów można łatwo scharakteryzować: przyczyną ideologicznego fermentu jest zwykle „wrogi element, rekrutujący się przeważnie z reemigrantów z Francji”, który na każdym kroku porównuje „stopę życiową górnika w Polsce do stopy życiowej we Francji, wychwalając stosunki panujące we Francji i stan ten wpływa ujemnie na mniej doświadczonych górników, co z kolei wpływa ujemnie na produkcję"96. To właśnie reemigrantów z Francji, którzy otwarcie deklarowali swoje niezadowolenie z warunków pracy i płacy, obarczano winą za niską wydajność pracy, słabe wyniki planów produkcyjnych oraz wydobycia węgla. Uważano też, że to ich sądy na temat warunków pracy i płacy w kopalniach francuskich podgrzewały nastroje i miały zły wpływ na pozostałą część załogi ${ }^{97}$. W raportach opartych na informacjach „źródeł

92 J. Chumiński, Wpływ aparatu bezpieczeństwa..., s. 25, 31, 36.

93 AIPN Wr, sygn. 053/256, Sprawozdanie miesięczne od 1 VIII do 3 IX $1951 \mathrm{r}$ dla szefa WUBP we Wrocławiu, Wałbrzych, 3 IX 1951 r., k. 114-115.

${ }^{94}$ R. Klementowski, Zgorzelecka bezpieka 1945-1990, Wrocław 2014, s. 90.

95 AIPN, sygn. 01265/2113, Raport do szefa WUBP we Wrocławiu z działalności grupy operacyjnej, Wałbrzych, 13 IX 1951 r., k. 121-122a; AIPN Wr, sygn. 032/76, Raport nr 1 o przebiegu rozpracowania obiektowego „Repatrianci z Francji” sporządzony przez PUBP w Wałbrzychu dla naczelnika Wydziału I WUBP we Wrocławiu, Wałbrzych, 9 V 1949 r., k. 7

${ }^{96}$ AIPN Wr, sygn. 053/256, Sprawozdanie miesięczne od 3 II do 4 III 1951 r PUBP w Wałbrzychu do szefa WUBP we Wrocławiu, Wałbrzych, 3 III 1951 r., k. 14.

97 Tamże, Sprawozdanie miesięczne od 1 I do 1 II 1951 r. PUBP w Wałbrzychu do szefa WUBP we Wrocławiu, Wałbrzych, 2 II 1951 r., k. 3; tamże, Sprawozdanie 
agenturalnych” pisano jakoby „Francuzi” uprawiali „wrogą propagandę w postaci powodowania drobnych awarii i szeptanej propagandy, która ma duży wpływ na wydobycie"98.

Zupełnie kuriozalne było podejrzewanie reemigrantów o celową działalność agenturalną na rzecz państwa francuskiego. W raportach nazywano to „celowym nasłaniem” przez państwo francuskie, a dowodami miały być zebrane materiały i informacje. Wroga działalność reemigrantów miała polegać na „szerzeniu wrogiej propagandy”, tzn. informowaniu górników o warunkach pracy w kopalniach francuskich ${ }^{99}$. W raportach UB pisano również, że francuski wywiad „wykorzystując sytuację [akcji reemigracyjnej - A.N.] przysłał [...] osoby celem prowadzenia roboty szpiegowsko-dywersyjnej"100.

Obiektem wzmożonej inwigilacji ze strony UB były osoby, które kontaktowały się z konsulatami francuskimi w Katowicach, Wrocławiu i Gdańsku, załatwiając formalności związane z powrotem do Francji. Dla urzędów bezpieczeństwa stały się ,celami obserwacji”, podejrzewanymi o szpiegostwo na rzecz państwa francuskiego, albo też potencjalnymi informatorami. W jednym z raportów pisano: „Zgodnie z wytycznymi MBP osoby [...] należy wszechstronnie prześwietlić w kierunku ustalenia faktycznego charakteru, kontaktu i ewentualnej ich przydatności do wykorzystania przez nas w rozpracowaniu konsulatu francuskiego w Katowicach, względnie w celu rozpracowania"101.

Intensywnie inwigilowani byli również naturalizowani Polacy posiadający francuskie paszporty. Funkcjonariusze UB przeprowadzali z nimi rozmowy, wymuszajacc przekazanie polskim władzom francuskich dokumentów. Częstą praktyką służb było także składanie rodzinom górniczym wizyt domowych, podczas których funkcjonariusze podawali się za dziennikarzy lokalnej prasy, zainteresowanych informacjami

miesięczne od 3 II do 4 III 1951 r. PUBP w Wałbrzychu do szefa WUBP we Wrocławiu, Wałbrzych, 3 III 1951 r., k. 15; AIPN Wr, sygn. 053/210, Sprawozdanie szefa UBP w Wałbrzychu od 1 V do 1 VI 1953 r. do szefa WUBP we Wrocławiu, 5 VI 1953 r., k. 77-78.

98 AIPN Wr, sygn. 053/868, Sprawozdanie Referatu Ochrony przy Kop[alni] „Mieszko”, Kontrwywiadowcza charakterystyka obiektu, Wałbrzych, 14 VIII 1953 r., k. 186, 224.

99 AIPN Wr, sygn. 053/256, Sprawozdanie miesięczne od 3 II do 4 III 1951 r. PUBP w Wałbrzychu do szefa WUBP we Wrocławiu, Wałbrzych, 3 III 1951 r., k. 15.

100 Tamże, Wykaz środowisk po linii PUBP w Wałbrzychu sporządzony przez szefa PUBP w Wałbrzychu dla szefa WUBP we Wrocławiu, Wałbrzych, 17 X 1951 r., k. $156-157$.

101 AIPN Wr, sygn. 032/76, Pismo naczelnika Wydziału I WUBP we Wrocławiu do szefa PUBP w Wałbrzychu, Wrocław, 30 XI 1951 r., k. 21. 
o górnikach z Francji. Podczas wizyt rodziny potwierdzały posiadanie ważnych francuskich paszportów i przyznawały, że czekają na okazję, aby móc wyjechać do Francji z cała rodzina, z powodu trudnych warunków życia w Polsce ${ }^{102}$.

$\mathrm{Na}$ początku $1950 \mathrm{r}$. wszystkie urzędy bezpieczeństwa otrzymały instrukcję dotycząca działań w stosunku do reemigrantów przybyłych z Europy Zachodniej, pt. Rozpracowanie obiektowe repatriantów. Mały plan. W późniejszym okresie akcji nadano kryptonim „Zachód-II”. Celem instrukcji było „wskazanie i rozpracowanie” prawie trzymilionowej grupy repatriantów z Zachodu, w tym z Francji, oskarżanych przez organy bezpieczeństwa o wrogi stosunek do „demokratycznego ustroju” Polski Ludowej ${ }^{103}$. Inwigilację uzasadniano również tym, że reemigranci z Zachodu (w tym z Francji), zajmowali wysokie stanowiska kierownicze i funkcyjne w aparacie państwowym, otrzymane zaraz po wojnie dzięki dużym kompetencjom zawodowym. W ocenie komunistycznych władz sprawowanie wysokich funkcji stanowiło „poważny obiekt zainteresowania obcych wrogich sił". Do tego ciagle powtarzano, że Zachód wykorzystuje polską emigrację do prowadzenia działalności szpiegowskiej przeciwko Polsce ${ }^{104}$.

Szeroko zakrojona akcja nie przyniosła jednak oczekiwanych rezultatów, głównie z powodu braków kadrowych i słabej organizacji. Raport WUBP we Wrocławiu uderza szczerością oceny. Naczelnik Wydziału I WUBP pisze, że „zagadnienie repatriantów z Francji na terenie naszego województwa przedstawia się dość krytycznie. Powiaty jak Wałbrzych (40 tys. repatriantów), Kłodzko (3 tys. repatriantów), Bolesławiec (1500 repatriantów) itd. nie posiadają ludzi w referacie I-szym interesującym się tym zagadnieniem. A sprawy są prowadzone [dorywczo A.N.] z powodu braku czasu, ponieważ pracownik prowadzacy referat I-szy musi prowadzić na swoim terenie wszystkie 3 sekcje Wydziału I, a przede wszystkim z trudem wykonuje samą zaległa korespondencję przesyłaną przez UBP"105. Mimo niepowodzenia szeroko zakrojonej obserwacji reemigrantów, zainteresowanie resortu bezpieczeństwa tym

${ }_{102}$ Tamże, Sprawozdanie Adamca z Komitetu Gminnego PZPR w Jedlinie-Zdroju do K[omitetu] P[owiatowego] PZPR w Wałbrzychu, Jedlina-Zdrój, 16 IX 1950 r., k. 10 .

${ }^{103}$ J. Wróbel, Na rozdrożu historii..., s. 592-593; tenże, Działania Ministerstwa Bezpieczeństwa Publicznego..., s. 209-215.

104 J. Wróbel, Na rozdrożu historii..., s. 594-595.

105 Tamże, s. 600-601; AIPN, sygn. 01355/34, Raport WUBP we Wrocławiu do naczelnika Wydziału III Departamentu I MBP w Warszawie, Wrocław, 5 IV 1951 r., k. 735 . 
środowiskiem nie malało, utrzymując się na podobnym poziomie jeszcze w latach $60 . \mathrm{XX}$ w. ${ }^{106}$

Tajne instrukcje MBP dotyczące rozpracowania środowiska reemigracyjnego stały $\mathrm{w}$ sprzeczności $\mathrm{z}$ oficjalnym stanowiskiem polskich władz dotyczącym repatriacji i reemigracji rodaków. Zamiast stabilnych warunków pracy i dostatniego życia zafundowano im pełna inwigilację, pozbawianie stanowisk, zwalnianie z pracy, kartki, kolejki. Atmosfera podejrzeń wobec środowisk polskich reemigrantów z Francji, przyzwyczajonych do wolności oraz swobody wypowiedzi i krytyki, była trudna do zniesienia. Serdecznie witani na dworcach kolejowych szybko stali się „wrogim elementem”, spiskującym z „obcym wywiadem”. Na tle zbiorowości Górnego i Dolnego Śląska wyróżniali się oni stylem życia, sposobem bycia, ubierania, etosem pracy oraz poglądami, wywołując niechęć lokalnych środowisk. Stało się to przyczyną narastania poczucia obcości, a nawet wyobcowania z lokalnych środowisk.

\section{Bibliografia}

Chumiński J., „Nowa inteligencja” $w$ polskich zaktadach przemystowych 1945-1956, „Kwartalnik Historyczny” 2006, nr 4, s. 17-45.

Chumiński J., Ruch zawodowy w Polsce w warunkach ksztattujacego się systemu totalitarnego: 1944-1956, Wrocław 1999.

Chumiński J., Wpływ aparatu bezpieczeństwa na sytuację kadrowa $w$ przemyśle polskim $w$ latach 1945-1956, w: „Budujemy socjalizm...”. Materiaty pokonferencyjne, red. R. Klementowski, S. Ligarski, Wrocław 2010, s. $19-45$.

Jarosz D., Pasztor M., Robineau, Bassaler i inni. Z dziejów stosunków polsko-francuskich w latach 1948-1953, Torun 2001.

Małkiewicz A., Październik 1956 r. w Watbrzychu, w: Październik na Ziemiach Zachodnich i Pótnocnych. Materiały seminarium naukowego, Mierki k. Olsztyna, wrzesień 1996, red. W. Wrzesiński, Wrocław 1997, s. 77-93.

Markiewicz W., Przeobrażenia świadomości narodowej reemigrantów polskich z Francji, Poznań 1960.

Ponty J., L’immigration dans les textes. France, 1789-2002, Berlin-Paris 2004. Retecki P., Górnictwo w Watbrzychu w latach 1945-1948, Wrocław 2010.

Turajczyk L., Polonijne organizacje społeczno-polityczne we Francji $i$ ich postawa wobec powrotu emigracji zarobkowej do kraju (1945-1948), „Materiały i Studia z Najnowszej Historii Polski” 3, 1967, s. 45-62.

${ }^{106}$ AIPN, sygn. 01265/1474, Charakterystyka po zagadnieniu wywiadu francuskiego i innych wchodzących w zakres zainteresowań Grupy IV Wydziału II [WUSW we Wrocławiu], Wrocław, 5 III 1963 r., k. 23-24, 30-31 (numeracja pdf). 
Turajczyk L., Spoteczno-polityczne organizacje polskie we Francji 1944-1948, Warszawa 1978.

Wspótzawodnictwo pracy $w$ życiu gospodarczym, społeczno-politycznym i propagandzie PRL, red. B. Tracz, Katowice 2008.

Aneta Nisiobęcka

Adaptation of repatriates from France to the communist reality of the Polish People's Republic in 1945-1954

(Summary)

After the end of World War II, the return from France to Poland of the "old" economic emigration (miners, farmers, and industrial workers), working mainly in the northern part of France, was very important for the authorities of Lublin's Poland. The incorporation of the so-called "Recovered Territories" into the Polish State, with their hard coal mines and large post-German estates made the Warsaw authorities to demand from Paris the return of the Polish citizens employed in French mines and agricultural farms. It was an obvious fact for the Polish government that the "forces from France" could play an important role in the development of the Polish mining industry. It was equally obvious that it was impossible to offer to them social conditions equalling those in France. The favourable attitude of repatriates could have been motivated mainly by ideological reasons. The Polish authorities relied upon the popularity of communist ideology within the communities of Polish miners in France, since this vast reservoir of people could remedy the shortage of staff both in the state administration, and the Polish Workers' Party. A strong bargaining argument of the Polish government was also the promise to increase their professional qualification.

But great enthusiasm generated by the return to the idealised fatherland was dampened by the reality of Stalinist Poland. Repatriates had to cope with financial difficulties, poor work conditions, housing scarcity, and also with surveillance by the Security Office and its local branches.

Aneta Nisiobęcka - pracuje w Archiwum Instytutu Pamięci Narodowej w Warszawie, historyczka i absolwentka Instytutu Bibliotekoznawstwa i Informacji Naukowej Uniwersytetu Warszawskiego, dr nauk społecznych w zakresie nauk o polityce. W swoich badaniach koncentruje się na historii emigracji polskiej we Francji oraz stosunków polsko-francuskich w XX w. Publikowała m.in. w: „Studiach Migracyjnych - Przeglądzie Polonijnym”, „Dziejach Najnowszych”, „Pamięci.pl”, „Biuletynie IPN”. 
Aneta Nisiobecka - employed at the Archive of the Institute of National Remembrance in Warsaw, graduate of history and Institute of Book Studies and Information of the University of Warsaw, $\mathrm{PhD}$ in political sciences. In her research she focuses on the history of Polish emigration in France and on Polish-French relations in the $20^{\text {th }}$ century. She publishes, among others, in such periodicals as Studia Migracyjne - Przeglad Polonijny, Dzieje Najnowsze, Pamięć.pl, and Biuletyn IPN.

E-mail: aneta.nisiobecka@interia.pl. 